Revista lus et Praxis, Año 25, No 1, 2019, pp. 131 - 194

ISSN 0717 - 2877

Universidad de Talca - Facultad de Ciencias Jurídicas y Sociales

La definición de la desaparición forzada en el derecho internacional Pietro Sferrazza Taibi

Trabajo recibido el 5 de diciembre de 2017 y aprobado el 12 de octubre de 2018

\title{
La definición de la desaparición forzada en el derecho internacional
}

\author{
THE DEFINITION OF ENFORCED DISAPPEARANCE \\ IN INTERNATIONAL LAW
}

Pietro Sferrazza Taibi ${ }^{*}$

\section{RESUMEN}

En este artículo se analiza la definición de la desaparición forzada con base en los tratados internacionales de derechos humanos específicamente dedicados a este crimen. Por tanto, se identifica cada uno de los elementos conceptuales y se explica su contenido considerando la doctrina, la jurisprudencia y la práctica de tribunales y órganos internacionales.

ABSTRACT

This article analyzes the definition of enforced disappearance based on international human rights treaties specifically dedicated to this crime. Therefore, each one of the conceptual elements is identified and its content is explained considering the doctrine, jurisprudence and practice of international tribunals and bodies.

PALABRAS CLAVE

Desaparición forzada, Derecho internacional de los derechos humanos, crímenes de lesa humanidad.

KEY WORDS

Enforced disappearance, International Law of Human Rights, crimes against humanity.

\section{Introducción}

La desaparición forzada de personas es una de las más atroces violaciones a los derechos humanos, debido a la brutalidad de sus conductas constitutivas y a la pluralidad de víctimas que involucra. La persona desaparecida, en efecto, no es la única afectada por este crimen, dado que su comisión vulnera los derechos de los familiares y otras personas cercanas e, incluso, cuando la desaparición viene cometida en el marco de crímenes de lesa humanidad, la

\footnotetext{
* Licenciado en Ciencias Jurídicas, Universidad de Valparaíso. Doctor en Estudios avanzados en Derechos Humanos, Universidad Carlos III (Madrid-España). Profesor de Derecho internacional público y Derecho constitucional de la Universidad Andrés Bello, Carrera de Derecho-Sede Viña del Mar, Facultad de Derecho, Quillota 980, Viña del Mar, Chile. Correo electrónico: pietrosferrazza@ gmail.com.
} 
sociedad en su conjunto sufre los embates de este ilícito, debido al carácter sistemático y generalizado de este tipo de crímenes, a la ausencia de información sobre las víctimas y al clima de temor e incertidumbre que se expande en el tejido social.

El presente trabajo tiene por objeto dar cuenta del desarrollo de la definición de la desaparición forzada en el Derecho internacional de los derechos humanos, tomando en consideración su regulación en los instrumentos internacionales dedicados específicamente a ella. Si bien se prestará especial atención a la definición consagrada en la Convención Internacional para la protección de todas las personas contra las desapariciones forzadas (en adelante, CIPPDF) ${ }^{1}$ por tratarse del instrumento internacional más reciente y con alcance universal, no se desatenderá su comparación con otros instrumentos internacionales sobre la desaparición; a saber: la Declaración sobre la protección de todas las personas contra las desapariciones forzadas (en adelante, DPPDF) ${ }^{2}$ y la Convención Interamericana sobre desaparición forzada de personas (en adelante, CIDFP) ${ }^{3}$. Si bien los instrumentos citados son más funcionales para imponer obligaciones internacionales a los Estados, en lo que se refiere a la responsabilidad penal individual también se tendrá presente la definición de la desaparición forzada como crimen de lesa humanidad contenida en el Estatuto de Roma (en adelante, ER) de la Corte Penal Internacional ${ }^{4}$.

Para cumplir con el objetivo general de analizar la noción internacional de la desaparición forzada, se tomarán en consideración las opiniones doctrinarias esbozadas sobre el tópico, la jurisprudencia y la práctica de tribunales y órganos internacionales y los trabajos preparatorios de los tratados aludidos, sobretodo de la CIPPDF. El presente trabajo se dividirá en cinco partes. La primera de ellas tiene un carácter introductorio y estará destinada a explicar la relevancia de una definición internacional de la desaparición. Las otras cuatro secciones se destinarán al análisis pormenorizado de cada elemento

\footnotetext{
1 Convención internacional para la protección de todas las personas contra las desapariciones forzadas, aprobada en Nueva York, 20 de diciembre de 2006, United Nations Treaty Series (en adelante, UNTS), vol. 2716, p. 3.

2 Declaración sobre la protección de todas las personas contra las desapariciones forzadas, aprobada por la Res. Nº 47/133 de la Asamblea General (en adelante, AG), 18 de diciembre de 1992.

${ }^{3}$ Convención Interamericana sobre Desapariciones Forzadas, Belem do Pará, AG/RES 1256 (XXIV-O/94), res. de 9 de junio de 1994 de la Asamblea General de la OEA.

${ }^{4}$ Estatuto de Roma de la Corte Penal internacional. Conferencia Diplomática de Plenipotenciarios de las Naciones Unidas sobre el Establecimiento de una Corte Penal Internacional. A/CONF.183/9, Roma, 17 de julio de 1998, UNTS, vol. 2187, p. 3.
} 
conceptual de la desaparición, esto es, la privación de libertad, la denegación de información, el sujeto activo y la sustracción a la protección de la ley ${ }^{5}$.

Sin duda, el tema de la definición internacional de la desaparición es de suma relevancia y no es del todo ajena al contexto nacional, no sólo porque Chile ha sufrido en carne propia su propio historial de desapariciones forzadas $^{6}$, sino también porque este crimen ha sido tipificado como un crimen de lesa humanidad en la legislación nacional ${ }^{7}$ y actualmente se está discutiendo en el Congreso Nacional su tipificación como un delito común ${ }^{8}$.

\section{La importancia de una definición}

Antes de abordar el análisis del problema conceptual, cabe preguntarse por qué es importante contar con una definición de la desaparición forzada y por qué es necesario plasmar esa definición en los instrumentos internacionales dedicados específicamente a la materia. Pues bien, la conceptualización de la desaparición forzada es indispensable para identificar con claridad cuáles son sus elementos constitutivos. En otras palabras, la definición nos muestra qué criterios deben ser satisfechos y qué antecedentes deben ser acreditados para considerar que se ha producido una desaparición forzada. La identificación de los elementos definitorios, además, facilita la determinación del contenido del derecho de toda persona a no ser sometida a este crimen, derecho consagrado a nivel convencional en el artículo 1 de la CIPPDF $^{9}$. Asimismo, la claridad sobre los elementos conceptuales de la desaparición incidirá en la actividad interpretativa de todas y cada una de las obligaciones internacionales dimanantes de los diversos instrumentos sobre el tópico. Finalmente, la definición es indispensable para ilustrar a los Estados la mejor manera para tipificar la desaparición como delito penal en el ordenamiento jurídico interno.

En el panorama actual sobre la codificación internacional de la desaparición forzada, todos los instrumentos internacionales que se han preocupado

\footnotetext{
${ }^{5}$ La naturaleza jurídica de este último elemento conceptual se discute, tal como se explicará en la sección 5.

${ }^{6}$ Para la documentación de las desapariciones cometidas en la dictadura de Pinochet, véase Comlsión Nacional de Verdad y Reconciliación (1996); Corporación Nacional de Reparación y ReConciliación (1996). Para conocer de qué manera se ha enfrentado el problema de las desapariciones en el contexto transicional chileno véase en los Informes Anuales de Derechos Humanos de la Universidad Diego Portales, los capítulos sobre verdad, justicia, reparaciones y memoria, redactados por la Prof. Cath Collins y el equipo del Observatorio de Justicia Transicional de dicha Universidad.

7 Ley No 20.357, de 2009.

8 Boletín No 9818-17, de 2014.

${ }_{9}^{9}$ McCrory (2007), p. 549.
} 
directamente de su regulación contienen una definición; a saber: la DPPDF, la CIDFP y la CIPPDF. También el ER contempla la desaparición como crimen de lesa humanidad. Dada la pluralidad de instrumentos internacionales que consagran una definición de la desaparición forzada, es conveniente transcribir las diversas definiciones. Así, el párrafo tercero del Preámbulo de la DPPDF prescribe que se trata del acto a través del cual "se arreste, detenga o traslade contra su voluntad a las personas, o que éstas resulten privadas de su libertad de alguna otra forma por agentes gubernamentales de cualquier sector o nivel, por grupos organizados o por particulares que actúan en nombre del gobierno o con su apoyo directo o indirecto, su autorización o su asentimiento, y que luego se niegan a revelar la suerte o el paradero de esas personas o a reconocer que están privadas de la libertad, sustrayéndolas así a la protección de la ley".

A su vez, la CIDFP señala en su artículo II que "se considera desaparición forzada la privación de la libertad a una o más personas, cualquiera que fuere su forma, cometida por agentes del Estado o por personas o grupos de personas que actúen con la autorización, el apoyo o la aquiescencia del Estado, seguida de la falta de información o de la negativa a reconocer dicha privación de libertad o de informar sobre el paradero de la persona, con lo cual se impide el ejercicio de los recursos legales y de las garantías procesales pertinentes".

Por su parte, el artículo 2 de la CIPPDF entiende que la desaparición forzada es "el arresto, la detención, el secuestro o cualquier otra forma de privación de libertad que sean obra de agentes del Estado o por personas o grupos de personas que actúan con la autorización, el apoyo o la aquiescencia del Estado, seguida de la negativa a reconocer dicha privación de libertad o del ocultamiento de la suerte o el paradero de la persona desaparecida, sustrayéndola a la protección de la ley".

Finalmente, el ER consagra la desaparición forzada como un crimen de lesa humanidad en el artículo 7(1)(i), definiéndola en el artículo 7(2)(i) como "la aprehensión, la detención o el secuestro de personas por un Estado o una organización política, o con su autorización, apoyo o aquiescencia, seguido de la negativa a admitir tal privación de libertad o dar información sobre la suerte o el paradero de esas personas, con la intención de dejarlas fuera del amparo de la ley por un período prolongado" ${ }^{\prime 10}$. Cabe hacer presente que de conformidad al art. 9 del ER, el crimen de genocidio, los crímenes de lesa humanidad y los crímenes de guerra, tipificados respectivamente en los arts. 6,

\footnotetext{
${ }^{10}$ Varios autores [FINUCANE (2010), p. 172; GIORGOU (2013), p. 1009] concluyeron que la definición del ER es un reflejo del Derecho Internacional consuetudinario previamente existente sobre la desaparición forzada.
} 
7 y 8 del Estatuto, podrán ser interpretados y aplicados con la ayuda de los Elementos de los Crímenes (en adelante, EC) ${ }^{11}$.

Cabe aclarar que la definición de la desaparición forzada como hecho ilícito internacional cumple una finalidad diferente a una definición de carácter penal nacional o internacional. En el primer supuesto, la definición está relacionada con la responsabilidad internacional del Estado, mientras que en el segundo se vincula con la responsabilidad penal de las personas natura$l \mathrm{~s}^{12}$. Este matiz debe tenerse a la vista a la hora de analizar la funcionalidad y el contenido de los elementos conceptuales de la desaparición forzada. En efecto, es lógico y justificable que los requisitos jurídicos para la configuración de la responsabilidad individual por la desaparición forzada sean más exigentes y requieran, eventualmente, la concurrencia de mayores elementos. Por ejemplo, el componente subjetivo de la desaparición puede ser relevante para la tipificación penal, pero menos determinante en la determinación de la responsabilidad internacional del Estado.

Tras una primera mirada a las definiciones existentes, salta a la vista que todos los instrumentos internacionales a que se ha hecho referencia ubican la desaparición en la parte dispositiva del texto, a excepción de la DPPDF, que la sitúa en el Preámbulo. Esta excepción no es fruto del azar, sino que refleja el triunfo de una postura que durante los trabajos preparatorios se

11 Elementos de los Crímenes, Asamblea de Estados Partes del Estatuto de Roma de la Corte Penal Internacional, primer período de sesiones, de 2002, ICC-ASP/1/3, art. 7(1)(i). Dichos elementos, contienen importantes explicaciones relativas a la desaparición forzada en los siguientes términos: "Crimen de lesa humanidad de desaparición forzada de personas. Elementos. 1. Que el autor: a) Haya aprehendido, detenido, o secuestrado a una o más personas; o b) Se haya negado a reconocer la aprehensión, la detención o el secuestro o a dar información sobre la suerte o el paradero de esa persona o personas. 2. a) Que tal aprehensión, detención o secuestro haya sido seguido o acompañado de una negativa a reconocer esa privación de libertad o a dar información sobre la suerte o el paradero de esa persona o personas; o b) Que tal negativa haya estado precedida o acompañada de esa privación de libertad. 3. Que el autor haya sido consciente de que: a) Tal aprehensión, detención o secuestro sería seguido en el curso normal de los acontecimientos de una negativa a reconocer la privación de libertad o a dar información sobre la suerte o el paradero de esa persona o personas; o b) Tal negativa estuvo precedida o acompañada de esa privación de libertad. 4. Que tal aprehensión, detención o secuestro haya sido realizada por un Estado u organización política o con su autorización, apoyo o aquiescencia. 5. Que tal negativa a reconocer la privación de libertad o a dar información sobre la suerte o el paradero de esa persona o personas haya sido realizada por un Estado u organización política o con su autorización o apoyo. 6. Que el autor haya tenido la intención de dejar a esa persona o personas fuera del amparo de la ley por un período prolongado. 7. Que la conducta se haya cometido como parte de un ataque generalizado o sistemático dirigido contra una población civil. 8. Que el autor haya tenido conocimiento de que la conducta era parte de un ataque generalizado o sistemático dirigido contra una población civil o haya tenido la intención de que la conducta fuera parte de un ataque de ese tipo".

12 McCrory (2007), p. 551; Rodley y Pollard (2009), p. 334. 
mostró renuente a la incorporación de la definición en el articulado de la Declaración. Éste no fue el único problema objeto de discusión durante la preparación de la Declaración, ya que se tardó mucho en alcanzar un consenso sobre los términos de la definición ${ }^{13}$. Para superar estas trabas, se optó por una solución de compromiso, incorporándose la definición en su lugar actual y calificándola como una definición de trabajo (working description). Rodley y Pollard destacan que la incorporación de esta definición fue positiva, pese a su ubicación en el Preámbulo, ya que contribuyó a identificar la esencia de la desaparición y sirvió como un punto de partida para dotar de contenido a las obligaciones internacionales relacionadas con esta práctica ${ }^{14}$. De todas formas y sin quitarle razón a estos autores, si lo que se pretende es incorporar una definición en un tratado internacional y no en una declaración, la técnica codificadora más adecuada es su plasmación en la parte dispositiva del texto, porque es indiscutibles que las cláusulas, disposiciones o artículos de un tratado, tienen fuerza jurídica vinculante. De ese modo, se sortea un eventual argumento que pretendiera sostener la no obligatoriedad de otras partes del tratado distintas a su articulado.

Tal como se ha comentado anteriormente, la desaparición forzada es un fenómeno que posee una naturaleza extremadamente compleja, porque su ejecución debe llevarse a efecto en diferentes etapas que se desarrollan, generalmente, durante un lapso considerable de tiempo y en las que suelen participar diversas personas desempeñando papeles diferentes, aunque con un propósito delictivo común ${ }^{15}$. De algún modo, la complejidad tiene incidencia en la identificación de los elementos constitutivos del concepto de desaparición forzada. En términos generales, se sostiene que tales elementos son tres; a saber: 1) la privación de libertad; 2) la denegación de información; y 3) el sujeto activo. Existe cierta discordia acerca de si la sustracción a la protección de la ley es un cuarto elemento conceptual o una consecuencia que se produce a raíz de la concurrencia de los elementos anteriores. Si bien los argumentos de las diferentes posturas acerca de la naturaleza jurídica de este elemento serán expuestos más adelante, cabe adelantar que la doctrina mayoritaria opta por la segunda de estas dos posiciones ${ }^{16}$.

\footnotetext{
13 Brody y González (1991), p. 376.

14 Rodley y Pollard (2009), p. 333.

15 De hecho, los EC, art. 7(1)(i), elemento 3, n. 23 y 27, reconocen explícitamente la complejidad de la desaparición forzada.

${ }^{16}$ Comisión de Derechos Humanos (en adelante, CDH) (2003), párr. 33: "la definición de las desapariciones forzadas debía contener por lo menos tres elementos constitutivos". Véase varias sentencias de la Corte Interamericana de Derechos Humanos (en adelante Corte IDH): Radilla Pacheco v. México,
} 
Es bueno concluir estos aspectos introductorios aclarando que la definición de la desaparición forzada ha conseguido un carácter consuetudinario en el Derecho internacional y ha adquirido una importancia capital para la comprensión de este ilícito ${ }^{17}$. A continuación, se procederá al análisis minucioso de cada uno de estos elementos, realizando un estudio comparado en atención a las definiciones de los diversos instrumentos internacionales antes transcritas.

\section{La privación de libertad}

La privación de libertad es una conducta central de la desaparición forzada, ya que con ella se inicia la ejecución de este ilícito ${ }^{18}$. En esta sección se analizará cómo ha sido incorporada esta conducta en las diversas definiciones internacionales de la desaparición. Asimismo, se reflexionará si la ilegalidad de la privación de la libertad es un requisito indispensable para la existencia de este crimen.

\subsection{La privación de libertad en las definiciones internacionales de la desaparición forzada}

Una primera cuestión que merece ser aclarada es que para la configuración de la desaparición forzada la privación de libertad puede ser realizada de cualquier manera. Esto significa que no es necesaria una modalidad específica de comisión de esta conducta. Sólo se requiere que la víctima sea privada de su libertad ${ }^{19}$.

Los instrumentos internacionales se refieren a este elemento con distintos sintagmas. Durante la negociación de la CIPPDF se barajaron al menos tres alternativas de redacción. La primera consistía en incorporar una cláusula genérica con un contenido semántico capaz de englobar toda forma de privación de libertad. Un buen ejemplo de esta propuesta es la fórmula empleada por la definición de la CIDFP ("privación de libertad cualquiera fuere su forma").

de 23 de noviembre de 2009, párr. 140; Ibsen Cárdenas e Ibsen Peña v. Bolivia, de 1 de septiembre de 2010, párr. 60; Chitay Nech y otros v. Guatemala, de 25 de mayo de 2010, párr. 85; Gomes Lund y otros ("Guerrilha do Araguaia") v. Brasil, de 24 de noviembre de 2010, párr. 104; Torres Millacura y otros v. Argentina, de 26 de agosto de 2011, párr. 95.

17 Giorgou (2013), p. 1006.

18 Modolell (2010), p. 202.

19 Grupo de Trabajo sobre Desapariciones Forzadas e Involuntarias (en adelante, GTDFi) (2011), pp. 17-21; Scovazzi y Citroni (2007), p. 272. Véase Corte IDH: Blanco Romero y otros v. Venezuela, de 28 de noviembre de 2005, párr. 105; Heliodoro Portugal v. Panamá, de 12 de agosto de 2008, párr. 192. 
Una segunda alternativa consistía en enunciar una lista exhaustiva de conductas privativas de libertad. Esta metodología fue empleada en la definición del ER, que enuncia tres tipos de acciones que privan de libertad a una persona -el arresto, la detención y el secuestro- y cuyo contenido semántico es relativamente amplio. Una tercera alternativa estribaba en la elaboración de una lista no exhaustiva de conductas privativas de libertad enunciadas como ejemplos, para luego agregar una expresión genérica que consagrare un numerus apertus. Esta es la opción escogida por la DPPDF ("se arreste, detenga o traslade contra su voluntad a las personas, o que éstas resulten privadas de su libertad de alguna otra forma") y la CIPPDF ("el arresto, la detención, el secuestro o cualquier otra forma de privación de libertad"). Las dos primeras propuestas fueron criticadas, la primera por ser imprecisa y la segunda por la imposibilidad de elaborar una lista exhaustiva de conductas privativas de libertad $^{20}$.

Habiéndose optado por la tercera alternativa de redacción, se debatió sobre las conductas que debían ser incorporadas como ejemplos. Los términos propuestos fueron muchos, pero en definitiva las conductas que quedaron consagradas en la definición fueron el arresto ${ }^{21}$, la detención ${ }^{22}$ y el secuestro ${ }^{23}$. Ambos y Böhm sugieren interpretar estas conductas de conformidad con el Conjunto de principios para la protección de todas las personas sometidas a cualquier forma de detención o prisión, un instrumento de soft law plasmado en una resolución de la Resolución Nº 43/173 de 9 de diciembre de 1988 de la Asamblea General de la ONU (en adelante, AG) ${ }^{24}$.

La interpretación de este instrumento debe ser amplia, dado que su objetivo es establecer pautas orientativas para la protección de todas las personas privadas de libertad. Según estos principios, el "arresto" es el acto de aprehender a una persona con motivo de la supuesta comisión de un delito o por un acto de autoridad. En cambio, la "detención" es la condición de toda persona detenida, esto es, una persona privada de libertad personal ${ }^{25}$. El Conjunto de principios no define al secuestro, pero en relación con la definición de la desaparición

${ }^{20} \mathrm{CDH}$ (2004), párr. 20; CDH (2005), párr. 19.

${ }^{21} \mathrm{CDH}$ (2005), párr. 19.

22 CDH (2003), párr. 36; CDH (2004), párr. 20; CDH (2005), párr. 19.

${ }^{23} \mathrm{CDH}$ (2005), párr. 19. Otros términos descartados fueron "encarcelamiento", "rapto", "internamiento" y "reclusión". Véase CDH (2003), párr. 36; CDH (2004), párr. 20.

${ }^{24}$ Амвоs у Вӧнм (2009), p. 232 у Conjunto de principios para la protección de todas las personas sometidas a cualquier forma de detención o prisión, Res. № 43/173 de la AG, 9 de diciembre de 1988.

${ }_{25}$ Conjunto de principios para la protección de todas las personas sometidas a cualquier forma de detención o prisión, "Uso de los términos", a), b) y d). Cabe señalar que los EC, art. 7(1)(i), elemento 
forzada es plausible interpretar que se trata de un término amplio referido a un hecho ilícito, a diferencia del arresto y la detención, que son actos sujetos al cumplimiento de exigencias jurídicas sustantivas y formales ${ }^{26}$.

El secuestro no ha recibido un tratamiento uniforme en el Derecho internacional público, ya que su regulación se ha realizado a propósito de fenómenos específicos relacionados con lucha contra el terrorismo, la criminalidad organizada transnacional ${ }^{27}$, el secuestro de niños ${ }^{28}$ y la entrega judicial ilegal ${ }^{29}$. La Resolución № 2.002/16 del Consejo Económico y Social (en adelante, Ecosoc), sobre la cooperación en la prevención, combate y eliminación del secuestro y la prestación de asistencia a las víctimas define en términos generales al secuestro, prescribiendo que "consiste en detener ilícitamente a una persona o personas en contra de su voluntad con la finalidad de exigir por su liberación un provecho ilícito o cualquier utilidad de tipo económico u otro beneficio de orden material, o a fin de obligar a alguien a que haga o deje de hacer algo", considerándolo como un delito grave, particularmente cuando se relaciona con las actividades de grupos delictivos organizados o grupos terroristas ${ }^{30}$.

Habiéndose analizado el debate sobre la mejor forma de incorporar la privación de libertad en la definición de la desaparición forzada, puede concluirse

1(a), n. 25, aclaran que el acto de la detención incluye los supuestos en que el autor mantiene una privación de libertad preexistente.

${ }^{26}$ Hall y Van Den Herik (2016), p. 287, concluyeron que el término "secuestro" comprende conductas no abarcadas por las nociones de arresto y detención.

27 Convención sobre la prevención y el castigo de delitos contra personas internacionalmente protegidas, inclusive los agentes diplomáticos, adoptada por la AG, res. 3166 (XXVIII), 14 de diciembre de 1973, UNTS, vol. 1035, p. 167, cuyo art. 2 (1)(a) incluye al secuestro como uno de los delitos que pueden cometerse contra las personas internacionalmente protegidas; Convención europea para la supresión del terrorismo, Consejo de Europa, 27 de enero de 1977, UNTS, vol. 1137, p. 93, cuyo art. $1(\mathrm{~d})$ prescribe que el secuestro y la toma de rehenes no se consideran delitos políticos para los efectos de la extradición; Convención internacional contra la toma de rehenes, adoptada por la AG, res. № 34/146,17 de diciembre de 1979, UNTS, vol. 1316, p. 205, art. 1, según el cual "Toda persona que se apodere de otra (que en adelante se denominará 'el rehén') o la detenga, y amenace con matarla, herirla o mantenerla detenida a fin de obligar a un tercero, a saber, un Estado, una organización internacional intergubernamental, una persona natural o jurídica o un grupo de personas, a una acción u omisión como condición explícita o implícita para la liberación del rehén, comete el delito de toma de rehenes en el sentido de la presente Convención".

${ }^{28}$ Convenio sobre los aspectos civiles de la sustracción internacional de menores, 25 de octubre de 1980, UNTS, vol. 2241, p. 424.

${ }^{29}$ La entrega judicial ilegal es un secuestro que tiene por finalidad someter a juicio una persona en un Estado distinto de aquél en que es secuestrada. Véase Costı (2002), pp. 57-99; RonZITTI (1965), pp. 64 y ss.; y RousSEAu (1930), p. 445.

30 Ecosoc (2002), párr. 1; Ecosoc (2003), párr. 16. 
que la fórmula escogida por la CIPPDF es adecuada, porque la enumeración de algunas conductas ejemplificativas permite superar la vaguedad de una cláusula genérica y porque la preferencia por una lista no exhaustiva de conductas evita que se realicen interpretaciones demasiado estrictas.

\subsection{La (i)legalidad de la detención y su configuración temporal}

Para que pueda configurarse una desaparición forzada es necesario que la privación de libertad adolezca de una ilegalidad, que contravenga las garantías establecidas por el ordenamiento jurídico. La ilegalidad de la privación de libertad comprende los supuestos en que una persona sufre una afectación de su libertad personal en contravención a normas jurídicas y también los casos en que dicha afectación sea arbitraria, esto es, carente de un fundamento razonable ${ }^{31}$.

Para la configuración de la desaparición forzada no es indispensable que la privación de libertad adolezca de ilegalidad ab initio, esto es, desde el momento mismo en que dicha conducta comienza a realizarse. En efecto, una privación de libertad que en su inicio cumpla con todos las garantías consagradas en el ordenamiento jurídico, podría ser constitutiva de desaparición forzada si en un momento posterior se torna ilegal ${ }^{32}$. Lo anterior podría ocurrir si se infringen las garantías de la persona privada de libertad mediante el ocultamiento o la denegación de la información a su respecto ${ }^{33}$. Un buen ejemplo es el caso Yrusta vs. Argentina resuelto por el Comité contra las Desapariciones (en adelante, CED). De acuerdo con los hechos, Yrusta era un interno que

\footnotetext{
31 Por lo general, en los sistemas internacionales de protección de los derechos humanos la protección de la libertad personal incluye una faceta formal que equivale al derecho a no ser privado de libertad ilegalmente y una faceta más sustantiva relacionada con el derecho no ser privado de libertad arbitrariamente. En el ámbito de la legalidad, es necesario que los ordenamientos internos regulen los supuestos en que procede la privación de libertad y los procedimientos con adecuadas garantías para practicarla. En cambio, la arbitrariedad puede configurarse cuando la privación de libertad no cumple con los requisitos del principio de proporcionalidad. Véase CORTE IDH : Gangaram Panday v. Surinam, de 21 de enero de 1994, párr. 47 ; Suárez Rosero v. Ecuador, de 12 de noviembre de 1997, párr. 41 ; "Niños de la Calle" (Villagrán Morales y otros) v. Guatemala, de 19 de noviembre de 1999 párrs. 132-134; Chaparro Álvarez y Lapo Íñiguez v. Ecuador, de 21 de noviembre de 2007, párr. 93. Véase Tribunal Europeo de Derechos Humanos (en adelante, TEDH): Van der Leer v. The Netherlands, de 21 de febrero de 1990, párr. 22; A. and others v. The United Kingdom, de 19 de febrero de 2009, párr. 164. Véase Comité de Derechos Humanos (en adelante, HRC): Van Alphen v. The Netherlands, de 23 de julio de 1990, párr. 5.8; Spakmo v. Norway, de 11 de noviembre de 1999, párr. 6.3.

32 CDH (2004), párr. 21; CDH (2005), párr. 20.

${ }^{33}$ Esposito et al. (2006), pp. 718-719. En el mismo sentido, EC, art. 7(1)(i), elemento 1(a), № 26, al prescribir que "en determinadas circunstancias, la aprehensión o la detención pudieron haber sido legales". Al respecto, véase Ambos (2014), p. 112; y Hall y Van Den Herik (2016), p. 287.
} 
fue trasladado desde un establecimiento penitenciario a otro, perdiéndose toda información a su respecto por un plazo de siete días. EI CED consideró que en este caso se produjo una desaparición forzada, aunque el inicio de la desaparición forzada haya sido legal y haya continuado siéndolo hasta la pérdida de la información sobre el paradero y situación de la víctima ${ }^{34}$.

En términos normativos debe tenerse en cuenta que la privación de libertad tiene una duración temporal que se prolonga mientras la persona permanezca despojada de su libertad personal. Por ende, es posible que la ilegalidad de la detención se produzca en el momento mismo en que principia la privación de libertad -por ejemplo, porque los agentes carecían de una orden judicial para la aprehensión o porque esta última no estaba fundada en un motivo legal-o en un momento posterior, cuando se oculta o deniega la información sobre el detenido. Lo imprescindible para la existencia de la desaparición es la configuración de la ilegalidad de la privación de libertad y no el momento en que ésta se produce ${ }^{35}$.

\section{La denegación de información}

La denegación de información es la conducta que integra la segunda fase de la desaparición forzada y consiste en la negativa u ocultamiento de la privación de libertad o de la información sobre la suerte y el paradero de la víctima. Se trata un acto esencial de la desaparición forzada, porque permite diferenciarla de otros crímenes, tales como el secuestro o la detención ilegal ${ }^{36}$. A continuación, se analizará en qué consiste esta conducta y el contenido de la información objeto de denegación. Asimismo, se realizará un paralelo entre la denegación de información como elemento conceptual de la desaparición forzada y el deber de información como obligación internacional del Estado. Esta sección continuará con la explicación de algunos problemas temporales inherentes a la configuración de la denegatoria de información y concluirá con el análisis de algunos problemas dogmáticos de naturaleza penal sobre la aplicabilidad de la conducta denegatoria de información a los agentes no estatales.

\footnotetext{
34 CED/C/10/D/1/2013, de 12 de abril de 2016.

35 Modolell (2009), p. 188; Modolell (2010), pp. 202-203, distinguiendo una ilegalidad previa de una ilegalidad concurrente. Véase CORTE IDH: Blanco Romero y otros v. Venezuela, cit., párr. 105; Heliodoro Portugal v. Panamá, cit., párrs. 191-192). Confróntese GTDFI (2008), párr. 7. En contra, MeINI (2009), p. 119.

36 Esposito et al. (2006), p. 719; López (2009), p. 90; Cryer (2010), p. 218]. Véase Corte IDH: Heliodoro Portugal v. Panamá, cit., párr. 198; Gómez Palomino v. Perú, de 22 de noviembre de 2005, párr. 103.
} 


\subsection{El contenido de denegación de información}

La denegación de información vulnera el deber de proporcionar información sobre la persona desaparecida a los interesados, deber cuya finalidad estriba en evitar la configuración de la desaparición forzada ${ }^{37}$. Por tanto, el cumplimiento de este deber mediante la entrega de la información sobre la situación de las personas privadas de libertad imposibilita que ellas sean sometidas a desaparición forzada. De acuerdo con las definiciones de los instrumentos internacionales sobre la desaparición, la denegación de información se plantea como una conducta cronológicamente posterior a la privación de libertad ${ }^{38}$, aunque dependiendo del caso, es posible que la privación de libertad se realice desde su inicio con la intención de ocultar el destino y el paradero de la víctima.

En la práctica, la denegación de información puede ser cometida de diferentes maneras, mediante una acción o una omisión ${ }^{39}$. Por ejemplo, la autoridad puede negar la información sobre la persona desaparecida desconociendo que la víctima haya sido privada de libertad o desconociendo que se poseen antecedentes sobre su situación. También es posible que la autoridad oculte intencionadamente la información impidiendo a los interesados su conocimiento. Finalmente, la autoridad puede destruir las fuentes de la información o entregar información falsa o tergiversada. En todas estas hipótesis se configura la conducta denegatoria de información ${ }^{40}$.

Ahora bien, es muy importante dilucidar cuál es el contenido exacto de la información que debe ser proporcionada a los interesados, aclarando a qué hechos específicos debe referirse. Las definiciones internacionales exigen que se proporcione información sobre el hecho mismo de la privación de libertad, el destino y el paradero de la persona desaparecida. Por lo tanto, las

\footnotetext{
37 Galain (2009), p. 149.

38 Todos los instrumentos internacionales, en efecto, utilizan la expresión "seguida de", salvo la DPPDF, que utiliza el sintagma "y que luego". Los EC, art. 7(1)(i), elemento 2(a) y (b), explicitan claramente que se trata de una conducta posterior a la privación de libertad.

39 AndREU-GuZmán (2001), p. 82.

40 Véase Andreu-Guzmán (2001), p. 82; Pérez (2006), p. 19; y Werle (2011), p. 530]. Hay muchos ejemplos jurisprudenciales de casos en que la autoridad estatal otorga información falsa. Por ejemplo, en el caso del TEDH, Kurt v. Turkey, de 25 de mayo de 1998, párrs. 16-18, las autoridades indicaron que la víctima había sido secuestrada por miembros del Partido de Trabajadores del Kurdistán (PKK). En el caso del HRC, Yasoda Sharma v. Nepal, de 28 de octubre de 2008, párr. 7.6, la autoridad informó que la persona desaparecida se había ahogado en un río mientras escapaba de un operativo de seguridad. En el caso del HRC, Zohra Madoui v. Algeria, de 28 de octubre de 2008, párr. 7.4, se comunicó que los problemas psiquiátricos de la víctima le habían impulsado al abandono de su hogar.
} 
autoridades competentes deben aclarar si la persona ha sido efectivamente privada de libertad e individualizar su paradero, esto es, la ubicación exacta del lugar en que se encuentra ${ }^{41}$. Respecto a la noción de destino se ha generado cierta discusión sobre su significado. En principio, lo básico es informar si la persona está viva o muerta ${ }^{42}$. Si la víctima ha muerto, debe proporcionarse información sobre la localización de sus restos mortales ${ }^{43}$. La omisión de la información sobre el estado de salud de la víctima no es trascendente para la valoración de la conducta denegatoria, porque sería excesivo concluir que se ha configurado un supuesto de desaparición forzada si la única información que no se proporciona es la relativa a su estado de salud ${ }^{44}$.

Pérez Solla argumenta que el contenido esencial de la información se refiere al paradero y destino de la persona desaparecida. En efecto, la negación de que la persona haya sido privada de libertad conlleva como consecuencia la denegación de información sobre su paradero y destino. Sin embargo, podría darse la hipótesis en que la autoridad reconoce la privación de libertad de la víctima, pero no otorga información sobre el paradero y el destino. Por ende, no siempre se impide la comisión de la desaparición mediante el simple reconocimiento de la privación de libertad ${ }^{45}$.

Pasando a otra cuestión, en la doctrina se ha discutido si es necesario algún tipo de requerimiento de información para que se configure la conducta denegatoria ${ }^{46}$. La conclusión más razonable obliga a concluir por no exigir ningún tipo de requerimiento, ya que de lo contrario se haría depender la configuración de la conducta denegatoria -y con ella, la de la desaparición forzada- del comportamiento de alguna persona interesada que solicite a la autoridad información sobre la persona desaparecida. Si bien es verdad que en la práctica los familiares de las víctimas y otras personas interesadas suelen solicitar información, también puede ocurrir que por diversas razones nadie pida información sobre la persona desaparecida. Lo anterior podría suceder por temor a represalias o por la inexistencia o ineficacia de una institucionalidad a la que se pueda solicitar formalmente información con algún grado

\footnotetext{
${ }^{41}$ Association for the Prevention of Torture (2006), p. 10.

42 Association for the Prevention of Torture (2006), p. 10.

${ }^{43}$ Vermeulen (2012), p. 177.

${ }^{44}$ Vermeulen (2012), p. 177.

45 Pérez (2006), pp. 13 y 19.

46 Meini (2009), p. 122. En contra Ambos (2014), t. II, p. 112; Werle (2011), p. 531, defendiendo la necesidad de requerimiento. La tipificación penal de la desaparición en Alemania sí exige un requerimiento. Véase Амвоs у Вӧнм (2009), р. 234.
} 
de certeza. En tales situaciones, no se puede hacer depender la configuración de la conducta denegatoria de un requerimiento previo de información, con lo cual no sería indispensable que el autor de dicha conducta reciba alguna petición que motive, exija, requiera, solicite o induzca el cumplimiento de su deber de proporcionar información sobre la persona desaparecida.

Es de suma importancia destacar el nexo que existe entre la denegación de información y el carácter permanente de la desaparición forzada. En efecto, la desaparición forzada es un ilícito que se sigue cometiendo hasta que se obtenga información sobre el destino y paradero de la persona desaparecida. Dicho de otro modo, la desaparición se prolonga hasta que la persona desaparecida reaparece; o sea puesta en libertad; o cuando se otorga la información sobre su privación de libertad, destino y paradero; o cuando se localizan, identifican de manera fidedigna y entregan sus restos mortales, en caso de que haya fallecido ${ }^{47}$.

\subsection{La denegación de información como elemento conceptual de la desaparición forzada y el deber de información como obligación internacional del Estado: similitudes y diferencias}

El artículo 18 de la CIPPDF impone a los Estados la obligación internacional de información en beneficio de los familiares del desaparecido y otras personas interesadas. Dicha norma especifica el contenido de esa información indicando que "cada Estado Parte garantizará a toda persona con un interés legítimo en esa información, por ejemplo los allegados de la persona privada de libertad, su representante o abogado, el acceso, como mínimo, a las informaciones siguientes: a) La autoridad que decidió la privación de libertad; b) La fecha, la hora y el lugar en que la persona fue privada de libertad y admitida en un lugar de privación de libertad; c) La autoridad que controla la privación de libertad; d) El lugar donde se encuentra la persona privada de libertad y, en caso de traslado hacia otro lugar de privación de libertad, el destino y la autoridad responsable del traslado; e) La fecha, la hora y el lugar de la liberación; f) Los elementos relativos al estado de salud de la persona privada de libertad; g) En caso de fallecimiento durante la privación de libertad, las circunstancias y causas del fallecimiento y el destino de los restos".

La obligación internacional de proporcionar información no debe confundirse con la conducta denegatoria de información como elemento conceptual

47 Véase Ambos (2014), p. 112; KYRIAKOU (2011), pp. 192-193. 
de la desaparición forzada de personas, porque el contenido y la naturaleza de cada una de estas instituciones son diferentes. La obligación de información tiene un contenido más amplio, detallado en el artículo 18. En cambio, la conducta denegatoria de información tiene un contenido más acotado, en cuanto se refiere a la privación de libertad, la suerte y el paradero de la persona desaparecida en los términos antes descritos. La obligación de información tiene una finalidad preventiva y debe ser objeto de cumplimiento por parte de los Estados. Desde ese punto de vista, es adecuado que la Convención Internacional haya sido específica en detallar la información que debe ser proporcionada a los interesados. Sin embargo, si en un supuesto de hecho no se otorga información sobre alguna de las cuestiones enumeradas en el art. 18, no se configura automáticamente la conducta denegatoria de la desaparición forzada. Por ejemplo, si la única información no proporcionada fuere la identidad de la autoridad que ha practicado la detención, sería exagerado concluir que se ha cometido una desaparición.

Por ende, la obligación internacional de proporcionar información como una medida de prevención de la desaparición forzada no debe ser confundida con la conducta denegatoria de información como elemento conceptual de este crimen. Se trata de una diferenciación muy importante para efectos prácticos. Por ejemplo, el art. 20(1) de la CIPPDF permite un cumplimiento limitado de la obligación de información en ciertos supuestos especiales y siempre que se cumplan algunos criterios normativos. Sin embargo, estas limitaciones no pueden regir respecto de la conducta denegatoria de información, porque de lo contrario se estaría limitando el derecho de toda persona a no ser objeto de una desaparición, derecho que posee un carácter absoluto y que no puede ser suspendido o limitado en ningún caso. Por ende, incluso en situaciones excepcionales el Estado debe proporcionar a la brevedad una información mínima a los interesados, que se refiera a la privación de libertad, el destino y el paradero de la persona desaparecida.

\subsection{La configuración temporal de la denegación de información}

En este punto se analizará el momento en que se inicia y termina la conducta denegatoria de información. Asimismo, se hará una breve referencia a la relación entre este elemento conceptual y el carácter permanente de la desaparición forzada.

Identificar el momento preciso en que se perfecciona la conducta denegatoria de información es una cuestión problemática. Ambos y Böhm han sostenido que el parámetro a considerar debe ser el plazo para dar cumplimiento al derecho de toda persona que viene privada de libertad a ser llevada sin 
demora ante un juez ${ }^{48}$. Generalmente, los ordenamientos jurídicos nacionales establecen plazos para el cumplimiento de esta garantía procesal, con lo cual puede inferirse que el deber de información debe ser satisfecho dentro de esos plazos ${ }^{49}$. Sin embargo, cabe preguntarse si el Derecho internacional ha regulado este asunto. Los tratados internacionales de derechos humanos se refieren al derecho a ser llevado sin demora ante un juez, pero no suelen establecer un plazo exacto, sino que emplean expresiones genéricas, tales como "sin dilación" o "sin demora" 50 . Ambos y Böhm han sostenido que este plazo no puede superar, en ningún caso, las cuarenta y ocho horas contadas desde el momento de la detención ${ }^{51}$.

En cuanto a la jurisprudencia internacional, en la sentencia Brannigan and McBride v. Reino Unido el Tribunal Europeo de Derechos Humanos (en adelante, TEDH) estimó que el Estado tenía un margen de apreciación que lo eximía de responsabilidad por la suspensión del derecho a ser llevado sin demora ante un juez. En este caso, atendido a la naturaleza terrorista de los delitos imputados a las personas privadas de libertad, el Tribunal estimó que la suspensión del cumplimiento de este derecho era justificada ${ }^{52}$.

\footnotetext{
48 Амвоs у Вӧнм (2009), рр. 233, 248 у ss.

${ }^{49}$ De hecho, el art. 10.1 de la DPPDF hace un reenvío al Derecho nacional.

${ }^{50}$ Entre los instrumentos internacionales sobre desaparición forzada, el derecho a ser llevado sin demora ante un juez está consagrado en la DPPDF, art. 10.1 y la CIDFP, art. XI. Además, este derecho está regulado en los siguientes tratados de derechos humanos: Pacto Internacional de Derechos Civiles y Políticos, adoptado y abierto a la firma, ratificación y adhesión por la AG, Res. № 2.200 A(XXI), 16 de diciembre de 1966, UNTS, vol. 999, p. 171, art. 9(3); Convención Americana sobre Derechos Humanos, Conferencia Especializada Interamericana sobre Derechos Humanos (b-32), San José, Costa Rica, 7 al 22 de noviembre de 1969, arts. 5(1)(c) y 5(3); Arab Charter on Human Rights, Liga de Estados Árabes, 22 de mayo de 2004, art. 8. Por su parte, el ER, art. 59.2, lo contempla como una garantía procesal del procedimiento ante la Corte Penal Internacional. Véase también el Conjunto de principios para la protección de todas las personas sometidas a cualquier forma de detención o prisión, principio 11.1. La Carta Africana sobre los Derechos Humanos y de Ios Pueblos (Carta de Banjul), aprobada el 27 de julio de 1981, XVIII Asamblea de Jefes de Estado y Gobierno de la Organización de la Unidad Africana, no hace referencia a este derecho, aunque la Comisión Africana de Derechos Humanos y de los Pueblos (en adelante CADHP), lo ha incorporado en algunos instrumentos de soft law: CADHP (2002), regla No 27; CADHP (1992), párr. 2(c); CADHP (2011), principios $M(3)$ y (4).
}

51 Амвоs у Вӧнм (2009), р. 248 у n. 208. Para defender esta tesis han recurrido a diversas fuentes. Por ejemplo, citan un estudio de Derecho comparado que analiza la duración del plazo en los países de América Latina, concluyendo que el plazo más extenso es de 48 horas: MALARINO (2003), p. 618, n. 168. También hacen referencia a la práctica del Comité Europeo para la Prevención de la Tortura y de las Penas o Tratos Inhumanos o Degradantes (en adelante, CPT), según la cual el plazo para notificar la detención no debe superar las cuarenta y ocho horas: CPT (2000), párrs. 22-23; CPT (2003), párrs. 13-14.

52 TEDH. Brannigan and McBride v. The United Kingdom, de 25 de mayo de 1993, párrs. 55-60. 
Afortunadamente, hay otras sentencias en que el TEDH ha adoptado una posición distinta. Por ejemplo, en el caso Brogan and others v. Reino Unido, que se refería a un contexto similar a la sentencia anterior, el TEDH consideró vulnerado el derecho a ser llevado sin demora ante un juez, porque había transcurrido un plazo de cuatro días y seis horas sin que se hiciera efectivo ${ }^{53}$. Esta sentencia ha servido como un referente para la jurisprudencia posterior ${ }^{54}$. En el caso McKay $v$. Reino Unido, el TEDH rebajó el plazo sosteniendo que el detenido debe ser llevado ante un juez antes del transcurso de cuatro días contados desde la detención ${ }^{55}$. Sin embargo, dependiendo de las circunstancias concretas del caso, el TEDH ha señalado que este derecho se ha infringido incluso habiendo transcurrido un plazo de menor duración ${ }^{56}$.

Por su parte, el Comité de Derechos Humanos (en adelante, HRC) ha sostenido que el plazo no puede exceder unos pocos días, aunque su exacta determinación debe realizarse caso a caso $^{57}$. Una posición similar es la que ha seguido el Grupo de Trabajo sobre Desapariciones Forzadas e Involuntarias (en adelante, GTDFI) en sus Observaciones Generales sobre el artículo 10 de la Declaración ${ }^{58}$. Finalmente, en el sistema interamericano, la Corte

\footnotetext{
${ }^{53}$ TEDH. Brogan and others v. The United Kingdom, de 29 de noviembre de 1988, párrs. 55-62.

${ }^{54}$ TEDH: Pantea v. Romania, de 3 de junio 2003, párrs. 241-243; Süleyman Yildirim v. Turkey, de 29 de julio de 2004, párr. 31; Öcalan v. Turkey, de 12 de mayo de 2005, párrs. 104-105. El caso Brogan and others v. Reino Unido, también ha sido citado por la CORTE IDH: Castillo Petruzzi y otros v. Perú, de 30 de mayo de 1999, párrs. 108-110.

55 TEDH. McKay v. The United Kingdom, de 3 de octubre de 2006, párr. 47. Para Casadevall (2012), pp. 257-258, el plazo de cuatro días es el plazo límite consolidado por la jurisprudencia del Tribunal de Estrasburgo, sin perjuicio de que los ordenamientos jurídicos de algunos Estados partes suelan contemplar plazos inferiores que fluctúan entre las veinticuatro y cuarenta y ocho horas.

56 Por ejemplo, en el caso Ípek and Others v. Turkey, de 3 de febrero de 2009, párrs. 36-37, en que el plazo fue de tres días y nueve horas, se consideró infringido el derecho, porque las personas privadas de libertad eran menores de edad y porque no se realizó otra diligencia investigativa que un interrogatorio. Asimismo, en el caso Kandzhov v. Bulgaria, de 6 de noviembre de 2008, párr. 66 , en que el plazo fue de tres días y veintitrés horas, también se consideró infringido el derecho, porque el delito imputado era de menor entidad y el fiscal decretó una extensión de la privación de libertad sin fundamentos razonables.
}

57 Confróntese HRC (2008), p. 213, párr. 2 y los siguientes casos: Stephens v. Jamaica, de 18 de octubre de 1995, párr. 9.6; McLawrence v. Jamaica, de 18 de julio de 1997, párr. 5.6. Refiriéndose al Derecho interno alemán, el HRC consideró que el plazo de 48 horas era demasiado extenso. Véase AG (1990), párr. 333.

${ }^{58}$ GTDFI (1997), párr. 29. 
Interamericana de Derechos Humanos (en adelante, Corte IDH) ha tomado en consideración los plazos que fijan los ordenamientos nacionales ${ }^{59}$.

A la luz de las anteriores explicaciones puede concluirse que el parámetro temporal para el ejercicio del derecho a ser llevado sin demora ante un juez viene fijado por la legislación nacional. Sin embargo, puede haber casos en que el Derecho interno no regule este plazo o éste sea demasiado extenso. Frente a este tipo de situaciones, no existe unanimidad en la práctica internacional sobre la cuantía del plazo para el ejercicio de este derecho, aunque todos los órganos internacionales concluyen que debe tratarse de un plazo breve ${ }^{60}$. De todo lo anterior, es plausible concluir la necesidad de que los ordenamientos nacionales regulen expresamente esta cuestión y fijen un plazo relativamente breve. Por lo tanto, si respecto de una persona privada de libertad no se otorga de oficio información dentro de este plazo, se configura la conducta denegatoria de información.

Pasando al segundo punto de análisis, en el marco de la responsabilidad internacional del Estado, la desaparición forzada viene calificada como un hecho internacionalmente ilícito permanente, o sea, una violación continua de una obligación internacional mediante la comisión de una acción u omisión que se prolonga en el tiempo ${ }^{61}$. Esta cualidad de la desaparición forzada tiene una relevancia significativa en relación con la activación de la competencia temporal o ratione temporis de los tribunales internacionales de derechos humanos ${ }^{62}$.

A su vez, en el marco del Derecho penal la desaparición forzada se considera un delito permanente. Si bien el análisis emprendido en este trabajo pretende no exceder los márgenes del Derecho internacional público, cabe mencionar la trascendencia que ha tenido el carácter permanente de la desaparición para el procesamiento y sanción de las desapariciones cometidas en Chile durante la dictadura cívico-militar de Augusto Pinochet. En efecto,

\footnotetext{
${ }^{59}$ Véase, por ejemplo, Corte IDH, "Niños de la Calle" (Villagrán Morales y otros) v. Guatemala, cit., párr. 133. Confróntese Rodríguez-Pinzón y Martin (2006), p. 126.

${ }^{60}$ Confróntese Amnistía Internacional (1998), pp. 84-85; Andreu-Guzmán (2001), p. 85; Association for the Prevention of Torture (2006), pp. 11, 15 y 17, sosteniéndose que el plazo puede superar una semana o dos, sin mayores precisiones y sin citar las fuentes que fundamentan esta conclusión; Rodley y Pollard (2009), pp. 450 y 458.

61 SALmon (2010), pp. 386. De conformidad con el art. 14(1) del Proyecto de artículos sobre Responsabilidad del Estado por Hechos Internacionalmente Ilícitos de la Comisión de DeRECHO INTERNACIONAL (2001), "la violación de una obligación internacional mediante un hecho del Estado que tiene carácter continuo se extiende durante todo el período en el cual el hecho continúa y se mantiene su falta de conformidad con la obligación internacional".

${ }_{62}$ Para un estudio del problema en relación con la Corte IDH, véase SferrazzA (2018), pp. 185-207.
} 
el carácter permanente de la desaparición desempeñó un importante papel a nivel jurisprudencial para demostrar la inaplicabilidad de la amnistía regulada en el Decreto Ley $N^{\circ} 2.191^{63}$ y de la prescripción de la acción penal ${ }^{64}$. Las desapariciones forzadas cometidas en la dictadura han sido juzgadas a nivel nacional por medio de la aplicación del delito de secuestro tipificado en el art. 141 del Código Penal vigente a la época de los hechos ${ }^{65}$. En la sentencia del año 2004 sobre el caso de la desaparición de Miguel Ángel Sandoval Rodríguez, la Corte Suprema sostuvo que el secuestro era un delito permanente ${ }^{66}$. Esta calificación imposibilita computar el plazo de prescripción del secuestro, porque sólo podría comenzar a contarse "una vez que ha concluido la duración de su estado consumativo" ${ }^{67}$, lo que ocurriría con el otorgamiento o descubrimiento de información sobre la persona desaparecida. Además, el carácter permanente del secuestro también imposibilita la aplicabilidad de la amnistía, porque sólo es aplicable a los delitos cometidos entre el 11 de septiembre de 1973 y el 10 de marzo de 1978, con lo cual si la perpetración del delito se extiende más allá de esta última fecha la amnistía es inaplicable ${ }^{68}$.

Sin perjuicio de lo anterior, la tesis del secuestro como delito permanente ha ido perdiendo importancia práctica para el juzgamiento de las desapariciones, desde que la jurisprudencia nacional ha venido defendiendo la inamnistiabilidad e imprescriptibilidad de los crímenes de lesa humanidad cometidos en la dictadura, mediante la aplicación del Derecho internacional de los derechos humanos y el Derecho internacional humanitario por la vía del art. 5 inciso segundo de la Constitución Política de la República ${ }^{69}$.

${ }^{63}$ Decreto Ley No 2.191, de 1978.

${ }^{64}$ La prescripción de la acción penal está contemplada en el art. 93 № 6 del Código Penal.

65 Guzmán Dalbora (2009), p. 67; Matus Acuña y Ramírez Guzmán (2017), p. 341.

${ }^{66}$ Corte Suprema, rol No 517-2004, 17 de noviembre de 2004, considerando 31. Para un comentario del caso, véase FernándeZ Neira (2010), pp. 475-476; Mañalich (2004), pp. 11-33, desarrollando varias críticas del fallo en relación con la noción del delito permanente y la inaplicabilidad de la amnistía y la prescripción desde la perspectiva de la teoría de la prevención general de la pena. Entre los penalistas que consideran el secuestro como un delito permanente, véase GuZMÁN DALBORA (2009), p. 67; Matus Acuña y Ramírez Guzmán (2017), p. 341.

${ }^{67}$ Corte Suprema, rol № 517-2004, cit., considerando 37. Véase Cury Urzúa (2005), p. 801.

${ }^{68}$ Corte Suprema, rol № 517-2004, cit., considerando 33.

${ }^{69}$ Un caso paradigmático en que se calificaron los crímenes de la dictadura como crímenes de guerra y crímenes de lesa humanidad, fue el de las ejecuciones extrajudiciales de Hugo Rivol Vásquez Martínez y Mario Edmundo Superby Jeldres. La Corte Suprema consideró que tales crímenes eran inamnistiables e imprescriptibles en atención a la aplicación de los Convenios de Ginebra, de la Convención sobre la Imprescriptibilidad de los Crímenes de Guerra y de los Crímenes de Lesa Humanidad como tratado que concretaba un efecto declarativo del Derecho consuetudinario sobre 


\subsection{La ejecución de la denegación de información por parte de agentes no estatales: un dilema dogmático}

Defender la posibilidad de que los agentes no estatales puedan ser autores de desapariciones forzadas, obliga a resolver algunos dilemas dogmáticos que surgen a propósito de la conducta denegatoria de información. En principio, el cumplimiento del deber de otorgar información sobre la persona desaparecida impera sobre los agentes estatales, en cuanto supone la existencia y funcionamiento de un aparato institucional capaz de brindar ciertas garantías a las personas privadas de libertad y de comunicar a los interesados la información pertinente sobre su situación. La CPPDF contiene una gama de deberes que tienen por objeto prevenir las desapariciones y que dicen relación con el otorgamiento de la información. Entre ellos cabe destacar: la prohibición absoluta de la detención secreta ${ }^{70}$, los requisitos para decretar órdenes privativas de libertad ${ }^{71}$, la regulación del registro de las personas privadas de libertad ${ }^{72}$ y de los lugares en que deben permanecer ${ }^{73}$, el derecho de comunicación ${ }^{74}$, el acceso de ciertas autoridades a los lugares de detención ${ }^{75}$, las garantías de la puesta en libertad ${ }^{76}$ y el derecho a la información ${ }^{77}$. Por tanto, en la medida en que los Estados cumplan con estos deberes, disminuye la probabilidad de denegación de información y, con ello, la eventualidad de que se configure la desaparición forzada.

la imprescriptibilidad y los deberes de respeto y garantía de la Convención Americana de Derechos Humanos, entre otros. Véase Corte Suprema, rol № 559-2004, 13 de diciembre de 2006, sentencia de casación, considerandos 6 y ss. y sentencia de reemplazo, considerandos 2 y ss. Para un comentario a este caso, véase Fernández NeiRA (2010), pp. 478-479. Esta tesis se aplicó luego al delito de secuestro. Por ejemplo, véase el caso sobre la desaparición de Ricardo Aurelio Troncoso Muñoz, Hernán Galo González Inostroza, María Elena González Inostroza y Elsa Victoria Leuthner Muñoz, Corte Suprema, rol No 3452-2006, 10 de mayo de 2007, considerandos 30 y ss. sobre la inamnistiabilidad y considerandos 68 y ss. sobre la imprescriptibilidad. Para un comentario a este caso, véase FernándeZ Neira (2010), pp. 480-481. Sobre el tratamiento jurisprudencial de la inamnistiabilidad, véase Matus, (2006), pp. 275-296.

${ }^{70}$ CPPDF, art. 17(1).

${ }^{71}$ CPPDF, art. 17(1).

72 CPPDF, art. 17(3).

${ }^{73}$ CPPDF, art. 17(1).

${ }^{74}$ CPPDF, art. $17(2)$.

${ }^{75}$ CPPDF, arts. 17(1)(e) y 12(3)(b).

${ }^{76}$ CPPDF, art. 21.

77 CPPDF, arts. 18 a 20. 
El problema es más complejo cuando los autores de la desaparición son agentes no estatales, dado que no todos ellos cuentan con el grado de organización necesaria para dar cumplimiento a este deber. Respecto de estos agentes, cabe preguntarse si es plausible que puedan Ilevarlo. En el caso de los agentes no estatales que actúan en conexión con el Estado, creemos que los deberes internacionales antes referidos siguen obligando al Estado, en atención a su estrecha conexión con el autor material de la desaparición.

Sin embargo, cuando se trata de agentes no estatales que actúan sin mantener una vinculación con el Estado, habrá que analizar en cada caso el contexto y la caracterización del agente. Tratándose de un grupo armado involucrado en un conflicto armado no internacional, el Derecho internacional humanitario fija algunos estándares mínimos en favor de las personas privadas de libertad. Tanto el art. 3 común a los Convenios de Ginebra ${ }^{78}$ como el Protocolo Adicional II (en adelante, Protocolo II) ${ }^{79}$, obligan a los grupos armados no estatales que actúan como beligerantes en un conflicto armado no internacional, al cumplimiento de ciertos deberes respecto de las personas privadas de libertad ${ }^{80}$. En efecto, el art. 3 común establece algunos estándares mínimos de humanidad, mientras que el Protocolo II regula un abanico de derechos de las personas privadas de libertad, siendo uno de ellos el derecho de comunicarse con el mundo exterior ${ }^{81}$. Además, las detenciones arbitrarias están prohibidas en el marco de un conflicto armado no internacional ${ }^{82}$.

Ahora bien, de no existir un conflicto armado no internacional el problema es más difícil de resolver respecto de agentes no estatales que actúan sin

\footnotetext{
78 I Convenio de Ginebra del 12 de agosto de 1949 para aliviar la suerte que corren los heridos y los enfermos de las fuerzas armadas en campaña, II Convenio de Ginebra del 12 de agosto de 1949 para aliviar la suerte que corren los heridos, los enfermos y los náufragos de las fuerzas armadas en el mar, III Convenio de Ginebra del 12 de agosto de 1949 relativo al trato debido a los prisioneros de guerra, IV Convenio de Ginebra del 12 de agosto de 1949 relativo a la protección debida a las personas civiles en tiempo de guerra, todos aprobados por la Conferencia Diplomática para Elaborar Convenios Internacionales destinados a proteger a las víctimas de la guerra, celebrada en Ginebra del 12 de abril al 12 de agosto de 1949.

79 Protocolo adicional a los Convenios de Ginebra del 12 de agosto de 1949 relativo a la protección de las víctimas de los conflictos armados sin carácter internacional (Protocolo II), aprobado en la Conferencia Diplomática sobre la Reafirmación y el Desarrollo Internacional Humanitario Aplicable en los Conflictos Armados, 8 de junio de 1977.

${ }^{80}$ Sobre la obligatoriedad del art. 3 común y el Protocolo II respecto de los grupos armados no estatales, véase Hill-CAWTHORne (2016), pp. 99-107, explicando por qué estos textos convencionales obligan a sujetos no estatales y aventurando una tesis sobre la obligatoriedad del Derecho consuetudinario humanitario sobre tal categoría de sujetos.

81 PAll, art. 5.2.b. Véase Melzer (2016), p. 209.

${ }^{82}$ Hill-Cawthorne (2016), pp. 91-ss.
} 
conexión con el Estado, porque carecen del nivel de organización necesario para dar cumplimiento al deber de otorgar información. Por lo demás, la discusión sobre estos agentes implica aceptar la tesis que defiende la plausibilidad de su autoría, cuestión sobre la que no existe acuerdo. Por ende, surgen dos problemas dogmáticos de Derecho penal que han sido abordados por la doctrina. En primer lugar, debe determinarse si los sujetos no estatales tienen el deber de proporcionar información, debiendo identificarse la fuente de la que dimana ese deber. En segundo lugar, debe valorarse si la imposición de ese deber genera una infracción al principio de no autoincriminación.

Ott y Giorgou niegan la posibilidad de que agentes no estatales denieguen información y sustraigan a la víctima de la protección de la ley, porque consideran que se trata de una conducta que sólo puede ser cometida por agentes del Estado ${ }^{83}$. Ambos y Böhm argumentan que el deber de brindar información ha sido concebido para obligar a los Estados, porque se relaciona con la protección jurídica de la gozan las personas privadas de libertad y su derecho de acceso a la justicia. Para estos autores, sólo las organizaciones no estatales asimilables a un Estado tienen la capacidad de incurrir en la denegación de información ${ }^{84}$.

En relación con la fuente de la que dimana el deber de información, se ha dado una interesante discusión entre los penalistas. Meini concibe la estructura típica de la desaparición como un delito de infracción a un deber y considera que la fuente del deber de información se produce por la injerencia relacionada con la privación de libertad. La injerencia es una noción penal que se utiliza para explicar la fuente de la posición de garante y que está relacionada con una actuación peligrosa o riesgosa que fundamenta la posición de garante. De acuerdo con la tesis de este autor, la privación de libertad es una conducta riesgosa para la personalidad jurídica de la víctima y da lugar a la posición de garante de la que surge el deber de otorgar información. Según Meini, ese deber sólo lo tienen los funcionarios públicos que han intervenido en la privación de libertad o que, sin haber intervenido en la privación de libertad, tienen el deber jurídico de custodiar el detenido ${ }^{85}$.

En cambio, Ambos y Böhm creen que la fuente del deber es la norma típica, porque es el tipo penal el que impone el deber de informar. Este mandato se desprende de la finalidad del cargo de funcionario público, que debe velar por el buen funcionamiento de la administración y por el bienestar de la

83 Ott (2011), p. 23; Giorgou (2013), pp. 1012-1013.

${ }^{84}$ Амвоs у Вӧнм (2009), рр. 246-248. Confróntese Отт (2011), рр. 25-27.

${ }_{85}$ MeINI (2009), pp. 122-123. 
ciudadanía. Para estos autores, sin embargo, el deber de información también lo detentan los agentes no estatales que actúan vinculados al Estado ${ }^{86}$. En un sentido similar, Modolell González considera que cuando las definiciones internacionales se remiten al apoyo o aquiescencia estatal, permiten que la fuente del deber de los agentes no estatales que actúan conectados al Estado sea justamente ese apoyo o aquiescencia estatal ${ }^{87}$.

Por su parte, Galain Palermo cree que la fuente de la posición de garante deviene de un deber especial extrapenal que tienen los funcionarios públicos por la calidad del cargo que envisten, aunque considera que los agentes no estatales que actúan vinculados al Estado actúan como una suerte de funcionarios públicos de hecho, pesando sobre ellos el deber especial extrapenal de otorgar información ${ }^{88}$.

A mi juicio, las argumentaciones de estos autores también pueden ser aplicadas a los agentes no estatales que actúan desvinculados del Estado. El nivel de problematicidad dependerá del concepto de agente no estatal que se maneje. Si se opta por una concepción restringida que exige una similitud con el Estado, no hay mayor impedimento para considerar que los agentes no estatales pueden cometer la conducta denegatoria en base a las mismas justificaciones anteriores. La cuestión se torna problemática si se maneja un concepto amplio de agente no estatal, porque en ese caso la fundamentación del deber parece ser más débil, ya que sólo podría sustentarse en la satisfacción del derecho a la verdad y el deber correlativo del autor de revelar lo ocurrido con las víctimas de desaparición, deber que en términos normativos parece tener menos fuerza que el deber de información atribuible a un funcionario público.

En cuanto al problema de la autoincriminación, López Díaz y Galain Palermo sostienen que si los agentes no estatales no tienen un deber institucional impuesto por ordenamiento jurídico que les obligue a proporcionar información, la revelación de esta podría traducirse en una autoincriminación ${ }^{89}$. Ambos y Böhm sostienen que la tipificación alemana de la desaparición es la más adecuada para sortear este problema, porque en ella la denegación de información sólo puede producirse si ha mediado un encargo previo del Estado o se ha incumplido un deber jurídico, con lo cual "ambas referencias están poniendo al sujeto en posición de garante, ya sea 'por su asimilación al

\footnotetext{
86 Амвоs у Вӧнм (2009), рр. 234 у 249.

87 Modolell González (2009), p. 191.

88 Galain Palermo (2009), pp. 158-162.

89 López Díaz (2009), pp. 81 y 97; Galain Palermo (2009), p. 149.
} 
cumplimiento de una función pública' -por actuar 'por encargo del Estado'-, lo cual lo situaría en la posición de funcionario público y le adjudicaría ese mismo cometido y el mandato de no incumplir con el deber de valar por el correcto funcionamiento de las instituciones y el respeto de los derechos que debe proteger; o por obligación 'cumplir un deber jurídico', que se funda en que el particular por propia decisión y sin orden estatal se alineó en una política estatal de desapariciones y en tal asimilación se ve vinculado por tanto a los deberes jurídicos que interna o internacionalmente se prevén para los funcionarios públicos ${ }^{\prime \prime 90}$. Respecto de los agentes no estatales desvinculados del Estado, no se ha planteado ninguna reflexión por parte de la doctrina. De todos modos, si se logra fundamentar que el agente no estatal tiene el deber de otorgar información y asume una posición de garante, difícilmente podría plantearse que a su respecto operaría el principio de no autoincriminación.

Como se ha podido comprobar, la posibilidad de que los agentes no estatales puedan incurrir en la conducta denegatoria depende de la posición que se asuma en estos debates dogmáticos penales. Aunque se trata de discusiones relativas a la responsabilidad penal individual, se ha considerado necesario dar cuenta de las principales posiciones doctrinarias a fin de demostrar la problematicidad que conlleva incorporar los agentes no estatales entre los autores de la desaparición forzada.

\section{El sujeto activo}

Sin lugar a duda, el tema del sujeto activo ha sido y sigue siendo objeto de una encendida polémica en la reflexión jurídica sobre la desaparición forzada. Las primeras conceptualizaciones de la desaparición consideraban que se trataba de un delito estatal, es decir, un delito cuyo sujeto activo debía ser un agente del Estado. En general, si se pasa revista a la práctica de la desaparición forzada en sus orígenes -por ejemplo, en la Unión Soviética, durante el régimen nazi o en las dictaduras latinoamericanas- es posible constatar que era el Estado el que ejecutaba, o al menos promovía, las desapariciones. Sin embargo, la dinámica de las desapariciones en ciertos contextos ha cambiado, obligando a reflexionar sobre la posibilidad de que agentes no estatales puedan cometer desapariciones, por ejemplo, en el marco de un conflicto armado no internacional, del terrorismo transnacional o de las dinámicas actuales de la criminalidad organizada. Por ende, ante contextos en que agentes no estatales participan de violaciones de derechos humanos que incluso pueden llegar a cometerse de manera sistemática o generalizada, cabe preguntarse

90 Амвоs у Вӧнм (2009), р. 235. 
de qué manera el Derecho se adapta a estas nuevas dinámicas y si necesita reformular alguno de sus postulados tradicionales.

Para abordar de modo sistemático los distintos problemas relacionados con este elemento conceptual, este epígrafe comenzará por tratar la cuestión de la clasificación y definición de las diferentes clases de agentes que pueden cometer la desaparición forzada. Luego, se dará cuenta de las posiciones enfrentadas sobre el agente no estatal en los travaux préparatoires de la CIPPDF. Finalmente, se analizará la noción de "organización política", incorporada en la tipificación de desaparición del ER como una categoría de sujeto activo.

\subsection{Clasificación y conceptualización de los sujetos activos}

Antes de abordar directamente la clasificación y definición de los sujetos activos de la desaparición, es prudente pasar revista a los instrumentos internacionales sobre desaparición forzada a fin de tener presente cómo ha sido regulado el sujeto activo en cada uno de ellos. La definición contenida el Preámbulo de la DPPDF considera que la desaparición puede ser cometida por "agentes gubernamentales de cualquier sector o nivel, por grupos organizados o por particulares que actúan en nombre del gobierno o con su apoyo directo o indirecto, su autorización o su asentimiento". La CIDFP, a su vez, esgrime que el delito puede cometerse por "agentes del Estado o por personas o grupos de personas que actúen con la autorización, el apoyo o la aquiescencia del Estado". Según la definición de la desaparición contenida en la CIPPDF, el delito puede ser cometido por "agentes del Estado o por personas o grupos de personas que actúan con la autorización, el apoyo o la aquiescencia del Estado". Sin embargo, el art. 3 de este tratado, dispone que "[l]os Estados Partes tomarán las medidas apropiadas para investigar sobre las conductas definidas en el art. 2 que sean obra de personas o grupos de personas que actúen sin la autorización, el apoyo o la aquiescencia del Estado, y para procesar a los responsables". Finalmente, para el ER, la desaparición puede ejecutarse "por un Estado o una organización política, o con su autorización, apoyo o aquiescencia".

El conjunto de estas referencias integra el material normativo a tener en cuenta para elaborar una conceptualización y clasificación de los sujetos activos de la desaparición forzada, cuestión que no ha sido muy tratada ni por la doctrina ni por la jurisprudencia. Por lo tanto, la clasificación y conceptualización que se construye y defiende en este trabajo pretende tener una base normativa en los instrumentos internacionales específicos sobre la desaparición. Una primera distinción que se asumirá es la que diferencia entre agentes estatales y agentes no estatales, atendiendo a si el autor pertenece o no a la estructura orgánica del Estado. Si se revisan las definiciones internacionales 
de la desaparición forzada es posible constatar que esta clasificación viene aceptada explícita o implícitamente ${ }^{91}$.

Ahora bien, entre los agentes no estatales debe realizarse una importante subclasificación que distinga entre los que tienen alguna vinculación con el Estado y los que no tienen relación alguna con el aparato estatal. El contenido de esta vinculación viene enunciado en las definiciones internacionales de la desaparición mediante los términos "autorización", "apoyo" y "aquiescencia"92. Entonces, entre los sujetos no estatales, habrá que distinguir entre aquellos que mantienen un vínculo con el Estado, porque actúan con su autorización, apoyo o aquiescencia y aquellos que están absolutamente desvinculados del Estado, porque actúan de manera autónoma, sin que concurra autorización, apoyo o aquiescencia del Estado ${ }^{93}$.

A la primera categoría de estos agentes no estatales hacen referencia todos los instrumentos internacionales sobre desapariciones forzadas. En cambio, los agentes no estatales "puros", "autónomos" o "independientes" sólo son objeto de regulación en el ER, cuando se refiere a la "organización política" y en la CIPPDF, que destina el art. 3 a esta clase de sujetos.

Ahora bien, en la doctrina, como se anticipaba, no se ha tratado con la atención que se requiere la cuestión de la clasificación y conceptualización del sujeto activo de la desaparición. Entre los autores que se han remitido a esta cuestión, Ambos y Böhm han señalado que los agentes estatales son aquellos que en su actuación se vinculan "de alguna manera" con el Estado ${ }^{94}$. Cabe interpretar a contrariu sensu que para estos autores los agentes no estatales actúan sin vincularse con el Estado de ninguna manera. Esta clasificación merece algunas reflexiones. En primer lugar, incluye en la noción de agente estatal a los sujetos que, sin pertenecer a la estructura orgánica del Estado, actúan con

\footnotetext{
91 Hacen referencia al agente estatal las expresiones "agentes gubernamentales de cualquier sector o nivel" (DPPDF); "agentes del Estado" (CIDPF y art. 2 de la CIPPDF) y "Estado" (art. 2 de la CIPPDF). En cambio, se remiten a los agentes no estatales los sintagmas "grupos organizados o [...] particulares que actúan en nombre del gobierno o con su apoyo directo o indirecto, su autorización o su asentimiento" (DPPDF); "personas o grupos de personas que actúen con la autorización, el apoyo o la aquiescencia del Estado" (CIDPF y artículo 2 de la CIPPDF); "organización política, o con [la] autorización, apoyo o aquiescencia [del Estado]" (ER) y "personas o grupos de personas que actúen sin la autorización, el apoyo o la aquiescencia del Estado" (art. 3 de la CIPPDF).

92 La DPPDF emplea el término "asentimiento" en cambio de "aquiescencia". Por otro lado, según el ER la autorización, apoyo o aquiescencia puede ser prestada por el Estado o por una organización política.
}

93 Generalmente, la actuación criminal de esta categoría de sujetos va de la mano con una incapacidad del Estado para contenerlos y perseguirlos. véase al respecto, GIORGou (2013), p. 1014.

94 Амвоs у Вӧнм (2009), р. 229. 
su apoyo, autorización o aquiescencia. Sin embargo, en la clasificación que se pretende defender en este trabajo, esos sujetos se consideran no estatales. En segundo lugar, la noción de agente estatal elaborada por estos autores atiende a la existencia de un vínculo entre agente y Estado, pero sin especificar en qué consiste esa vinculación. Sin embargo, la clasificación que se propone se centra en un tipo específico de vínculo, que consiste en la pertenencia del sujeto a la estructura del Estado, criterio que este trabajo considera central para diferenciar entre agentes estatales y agentes no estatales.

Por su parte, Andreu-Guzmán concibe dos clases de agentes estatales: los directos, esto es, aquellos que forman parte de la estructura orgánica del Estado y los indirectos, es decir, particulares que actúan con la autorización, apoyo o aquiescencia del Estado ${ }^{95}$. Esta clasificación también merece algunas reflexiones críticas. Los términos "directo" e "indirecto" no son precisos y pueden inducir a confusión, ya que, según el diccionario de la Real Academia Española, directo es algo "[q]ue se encamina derechamente a una mira u objeto", mientras que indirecto es algo que "[q]ue no va rectamente a un fin, aunque se encamine a él"96. Sin embargo, las dos tipologías de agentes a los que se refiere este autor, los directos y los indirectos, dirigen su comportamiento derechamente hacia la comisión de la desaparición. Un planteamiento de esta naturaleza podría conducir a la conclusión errónea de que la desaparición cometida por un agente indirecto tiene menos gravedad que la cometida por un agente directo. Finalmente, la clasificación no incluye a agentes no estatales que actúen sin tener una vinculación con el Estado.

Otros autores han propuesto clasificaciones basándose en las características de hecho de los sujetos activos de las desapariciones forzadas. Huhle, miembro actual del Comité contra las Desapariciones Forzadas (en adelante, CED), ha diferenciado las siguientes clases de sujetos: 1) sujetos que de una manera visible actúan a nombre del Estado (partner of a state), por ejemplo, una empresa privada de seguridad; 2) sujetos cuya vinculación con el Estado se mantiene oculta o secreta, por ejemplo, una organización paramilitar; 3) sujetos que actúan con la aquiescencia estatal; 4) grupos de oposición armada; 5) movimientos de insurrección nacional que se convierten en un Gobierno o cuasigobierno y grupos que ejercen de facto funciones estatales; 6) organizaciones criminales sin objetivos políticos y desvinculados de autoridades estatales ${ }^{97}$.

\footnotetext{
95 Andreu-Guzmán (2001), p. 82.

96 Real Academia Española (2018).

97 Huhle (2013), p. 24.
} 
En una línea similar, Alston, en su calidad de Relator Especial sobre las Ejecuciones Extrajudiciales, Sumarias o Arbitrarias, focalizándose en la afectación del derecho a la vida, especialmente, en los asesinatos cometidos por agentes no estatales, ha distinguido cuatro clases de agentes: 1) sujetos que "Ilevan a cabo sus acciones a instancias del gobierno, o con su conocimiento o aquiescencia", por ejemplo, "grupos paramilitares, milicias, escuadrones de la muerte, tropas irregulares"; 2) "[a]gentes o asesores privados subcontratados que, aunque no son en ningún sentido funcionarios gubernamentales, ejercen funciones que corresponderían al Estado", por ejemplo, "la administración de prisiones, los servicios de represión, los servicios de interrogatorios"; 3) sujetos particulares; 4) grupos de oposición armada ${ }^{98}$.

Este tipo de clasificaciones tienen la utilidad de ilustrar la diversidad de agentes no estatales que pueden estar involucrados en la comisión de desapariciones forzadas. Por ende, desde el punto de vista sociológico son clasificaciones interesantes. Sin embargo, es posible plantear algunas críticas. No está del todo claro el criterio distintivo para realizar la categorización, aunque asumimos que se trata de las características fácticas del agente. Por otro lado, son clasificaciones no exhaustivas, porque dada la diversidad de sujetos no estatales existentes y sus variopintas características, es difícil elaborar una enumeración capaz de englobarlos a todos. De hecho, el concepto mismo de agente no estatal no es suficientemente claro en la doctrina internacionalista. Finalmente, no se trata de clasificaciones normativas, porque no se basan en un criterio diferenciador que tenga una base jurídica y que permita a su vez ofrecer categorías útiles para problemas jurídicos, por ejemplo, en relación con la determinación de la responsabilidad internacional del Estado.

La clasificación que se propone en este trabajo tiene la ventaja de asentarse en las definiciones de la desaparición de los instrumentos internacionales. El contenido de los deberes internacionales que surgen de tales instrumentos puede asumir matices distintos en relación a si el agente de la desaparición es estatal o no estatal, con lo cual la clasificación que se propone tiene por objeto ofrecer categorías funcionales para la interpretación del contenido de tales deberes. De todos modos, cabe señalar que, en todo supuesto de desaparición forzada, se configura la responsabilidad internacional del Estado, aunque en atención al tipo de agente que la comete, es posible que los deberes internacionales que el Estado deba cumplir sean parcialmente distintos.

${ }_{98} \mathrm{CDH}$ (2004b), párrs. 69-76. 
Para comprender la clasificación propuesta en esta sección es indispensable explicar qué se entiende por autorización, apoyo y aquiescencia ${ }^{99}$. Se trata de nociones amplias que no pueden ser definidas con una precisión absoluta y de las que se valen los instrumentos internacionales para abarcar un amplio abanico de supuestos en que el autor detenta un vínculo o conexión con el Estado. Según Pérez Solla, la autorización consiste en una orden directa del Estado $^{100}$. La misma autora sostiene que el apoyo equivale al consentimiento estatal ${ }^{101}$. Respecto de la aquiescencia, ella señala que consiste en tener conocimiento sobre la actual o potencial ejecución de desapariciones forzadas, omitiéndose las actuaciones necesarias para evitar su comisión, esto es, tolerando su ejecución ${ }^{102}$.

Estas nociones tienen por objeto valorar el vínculo entre el Estado y el autor de la desaparición, vínculo que en la práctica puede asumir formas muy variadas, desde un comportamiento muy proactivo de los agentes estatales hasta la mera tolerancia. Quizás, las apreciaciones de Pérez Solla son imprecisas en lo que se refiere a la autorización y el apoyo. La autorización parece hacer referencia a una suerte de permiso positivo fáctico y antijurídico para la comisión del crimen, entendido como la ausencia de una prohibición estatal de cometer la desaparición ${ }^{103}$. El plano de razonamiento, sin embargo, es de tipo fáctico. Dicho de otra manera, no necesariamente se refiere a la ausencia de una norma jurídica de prohibición, sino a un estado de hechos de facto en que es posible percibir que el Estado es proclive y permite que se cometa la desaparición. Por su parte, el apoyo implica una contribución efectiva a la realización de la desaparición, sin que los agentes estatales intervengan en su ejecución material. De todos modos y con independencias

\footnotetext{
99 Según los EC, art. 7(1)(i), elementos 4 y 5, en el acto de privación de libertad puede ser ejecutado con autorización, apoyo o aquiescencia del Estado, a diferencia de la denegación de información, que sólo puede ser realizada con autorización o apoyo. Según WitSCHEL y RüCKERT (1999), p 102, esta diferencia se debe a un error en la adaptación de las distintas versiones idiomáticas del texto.

100 Pérez (2006), p. 12.

101 Pérez (2006), p. 12.

102 Pérez (2006), p. 12. Confróntese Giorgou (2013), p. 1014, n. 55, para quien la aquiescencia es una forma pasiva de participación estatal que incluye aprobación, acuerdo o consentimiento, que puede adoptar varias manifestaciones expresas o tácitas y que puede ser otorgada antes o después de la perpetración del crimen. Para un concepto general de aquiescencia véase Müller y COTTIER (1992), p. 14, aclarando que en el Derecho internacional se refiere a situaciones de inactividad o pasividad de un sujeto frente a una reclamación, pero que generan efectos jurídicos obligatorios. Esta conceptualización es más precisa en relación con la noción planteada por GıorGou, ya que es más acorde a la realidad de la ejecución de la desaparición generalmente realizada por sujetos no estatales, pero sin que el Estado evite la comisión del hecho teniendo conocimiento de este.

103 Para la noción de permiso en el campo de la lógica deóntica, véase Alexy (2008), pp. 175-177.
} 
de estas disquisiciones, lo aconsejable es interpreta amplia y casuísticamente estos conceptos, con la finalidad de que se pueda valorar en cada supuesto si existe algún tipo de vínculo entre el autor material y el Estado ${ }^{104}$.

Las explicaciones sobre las diversas categorías de agentes permiten abordar con pie firme el debate que tuvo lugar durante los trabajados preparatorios de la CIPPDF sobre la incorporación del sujeto activo en la definición de la desaparición.

\subsection{Las posiciones enfrentadas sobre el agente no estatal en los trabajos preparatorios de la Convención Internacional para la Protección de todas las Personas contra Desapariciones Forzadas}

La revisión de los travaux préparatoires de la CIPPDF permite inferir que los redactores estaban de acuerdo en considerar a los agentes estatales como autores de la desaparición forzada ${ }^{105}$. Sin embargo, algunas delegaciones eran favorables a la incorporación de los agentes no estatales como sujetos activos de este crimen ${ }^{106}$. Esta discrepancia también estaba y sigue estando presente en la doctrina especializada ${ }^{107}$.

\footnotetext{
104 A modo de analogía, puede hacerse referencia a la definición de tortura del art. 1 de la Convención contra la Tortura y otros Tratos o Penas Crueles, Inhumanas y Degradantes, adoptada y abierta a la firma, ratificación y adhesión por la AG, res. 39/46, 10 de diciembre de 1984, UNTS, vol. 1465, p. 112, que emplea los términos "consentimiento o aquiescencia". Según VILLÁN DurÁN (1985), pp. 395-396, estas expresiones permiten incluir en el concepto de tortura las actuaciones de organizaciones no estatales, por ejemplo, los paramilitares. En la misma línea, NowAK y McArthur (2008), p. 78, para quienes estas expresiones cubren un amplio rango de actuaciones cometidas por particulares, siempre que el Estado permita de alguna manera que el comportamiento se cometa o continúe. Incluso, señalan que un ejemplo de tortura cometida con la aquiescencia del Estado, sería la cometida por una empresa de seguridad privada, siempre que los agentes estatales supieran o deberían haber sabido que dicha empresa podía recurrir a la tortura.
}

${ }^{105} \mathrm{CDH}$ (2004), párr. 32.

106 Confróntese Subcomisión de Prevención de Discriminaciones y Protección a las Minorías (1996), párr. 46; Subcomisión de Prevención de Discriminaciones y Protección a las Minorías (1998), párr. 22. Durante la preparación de la Convención, las organizaciones no gubernamentales y agrupaciones de familiares de personas desaparecidas manifestaron su contrariedad a la inclusión de los agentes no estatales. Confróntese Diez-BACAlso (2007). En contra, Huhle (2013), p. 23, argumentando que el papel principal de las organizaciones no gubernamentales debe ser la protección de las víctimas, con independencia de que el autor sea un agente estatal o no estatal.

107 Entre los partidarios de la estatalidad del autor: Courtney (2010), pp. 682 y 686; y Parayre (1999), p. 30. Entre los autores favorables a la inclusión de los agentes no estatales, ANDERSON (2007), p. 256; Scovazzi y Citroni (2007), p. 279; Vermeulen (2011), p. 154; y Giorgou (2013), pp. 1004-1008, quien sobre la base del carácter tradicionalmente estatal de la desaparición forzada, acepta la extensión de la autoría sólo respecto de agentes que sean asimilables a los Estados (State-like organizations). En el marco del Consejo de Europa también se ha defendido una posición favorable a la inclusión 
Tradicionalmente, los Estados han sido reacios a cualquier clase de reconocimiento internacional de los sujetos no estatales. Incluso, en algunos contextos los Estados consideran a ciertos sujetos no estatales como enemigos internos. Piénsese en los grupos de oposición armada, los movimientos insurreccionales, las agrupaciones terroristas o en cualquier otra clase de sujeto que persigue la finalidad política de derrocar o debilitar al Estado. Por ende, el reconocimiento de derechos u obligaciones internacionales de los agentes no estatales viene interpretado por los Estados como un reconocimiento de subjetividad internacional. Las autoridades estatales, por ende, intentan evitar que los sujetos no estatales se erijan en igualdad de condiciones ante a la comunidad internacional mediante la adquisición de márgenes de subjetividad y hacen todo lo que esté a su alcance para tratarlos como criminales y someterlos a la aplicación del Derecho penal nacional ${ }^{108}$.

Sin embargo, los agentes no estatales han ido ganando cada vez más protagonismo en diversas áreas del Derecho internacional y, por cierto, en el Derecho internacional de los derechos humanos. Entre los factores que han incidido en este fenómeno, Alston destaca la globalización, la privatización de los servicios públicos, el flujo y multiplicación de los capitales privados, la liberalización de los mercados y el fortalecimiento de la sociedad civil ${ }^{109}$. Asimismo, la diversificación de los conflictos armados contemporáneos y la proliferación de los denominados conflictos asimétricos están demandando una respuesta más coherente por parte del Derecho internacional humanitario ${ }^{110}$. Sobre la base de todo lo anterior, hoy en día es evidente que los agentes no estatales no sólo tienen la capacidad de violar derechos humanos y de ser responsables por tales violaciones, sino que también tienen la posibilidad de protegerlos.

Cabe especular que las divergencias sobre la naturaleza del autor de la desaparición que tuvieron lugar durante la negociación de la CIPPDF son un reflejo de la discusión más general sobre la problemática de los agentes no

de los actores no estatales. Véase Asamblea Parlamentaria del Consejo de Europa (2005), párr. 46; Asamblea Parlamentaria del Consejo de Europa (2005c), párr. 10.1.1.

108 Clapham (2010), pp. 562 y 576.

109 Alston (2005), pp. 17-19. Clapham (2006), pp. 3-23 y Clapham (2010), pp. 564-566, identificando cuatro fenómenos que influyen en el protagonismo de los actores no estatales y que motivan una respuesta por parte del Derecho internacional de los derechos humanos: la globalización, la privatización, la fragmentación y la feminización. Según BöRzel y RISSE (2013), pp. 65-84, la debilitación de los Estados en el ejercicio de la autoridad pública y en el monopolio de la fuerza ha otorgado protagonismo a entidades no estatales.

110 Clapham (2010), pp. 565-566, refiriéndose a este proceso con el nombre de "Fragmentación de los Estados" (Fragmentation of States); FleCK (2003), p. 70. 
estatales en el Derecho internacional ${ }^{111}$. En el marco de los trabajos preparatorios, los partidarios de la exclusividad de la responsabilidad de los agentes estatales argumentaban que la incorporación de sujetos no estatales podía incidir negativamente en la determinación de la responsabilidad internacional del Estado. Se trata de un argumento general comúnmente invocado por quienes consideran que el Estado es el único sujeto capaz de violar derechos humanos. De acuerdo con esta idea, si el marco de las responsabilidades internacionales se flexibiliza incluyendo agentes no estatales, los Estados harán todo lo posible para desviar su propia responsabilidad hacia ellos ${ }^{112}$. Sin embargo, esta posición puede ser criticada. De acuerdo a la tesis de Clapham, los sujetos no estatales pueden ser responsables de violaciones a los derechos humanos, aunque no participen en los procesos de creación del Derecho internacional, con lo cual el Derecho internacional de los derechos humanos debe adaptarse a estas nuevas necesidades y el riesgo de nuevas violaciones por parte del Estado debe sopesarse con el imperativo de responsabilizar a nuevos actores capacitados para violar derechos humanos ${ }^{113}$. Además, con independencia de la discusión sobre la responsabilidad internacional de agentes no estatales, debe tenerse muy presente que el Estado también puede ser responsabilizado frente violaciones a los derechos humanos cometidas por sujetos no estatales, si no ha empleado los medios a su alcance para prevenir su comisión o responsabilizar a los culpables ${ }^{114}$.

Las violaciones de los derechos humanos pueden activar la operatividad de una pluralidad de regímenes de responsabilidad tanto a nivel individual como a nivel estatal. Por ejemplo, si la desaparición forzada satisface los requisitos de los crímenes de lesa humanidad, además de la responsabilidad internacional del Estado, surgirá también la responsabilidad penal internacional de los perpetradores. Por lo tanto, una protección integral de los derechos humanos requiere que los diferentes regímenes de responsabilidad puedan aplicarse armónicamente. Dicho lo anterior, si el autor de la violación es un sujeto no estatal, habrá que constatar en cada caso si se reúnen los requisitos para la configuración de su responsabilidad penal individual. Pero además, debe determinarse si surge la responsabilidad internacional del Estado por su participación o por su falta de diligencia debida en la prevención y sanción

\footnotetext{
111 HUHLE (2013), p. 23.

112 Subcomisión de Prevención de Discriminaciones y Protección a las Minorías (1996), párr. 46; CDH (2005), párr. 31.

113 Clapham (2010), pp. 562-563; Clapham (2006), pp. 25, 32 y 43.

114 Para la defensa de la responsabilidad estatal por hechos de agentes no estatales durante los trabajos preparatorios, CDH (2003), párr. 35; CDH (2005), párr. 40.
} 
del crimen. Si los regímenes de responsabilidad se aplican conjunta y armónicamente, el argumento según el cual el Estado eludiría subrepticiamente su responsabilidad pierde sentido. En tales situaciones, habría que imputar a cada sujeto las ilicitudes que cometan, aplicándose los estándares adecuados para cada situación ${ }^{115}$.

Según otro argumento de la postura favorable a la exclusividad estatal, la inclusión de los agentes no estatales desfiguraría el esquema tradicional del Derecho internacional de los derechos humanos ${ }^{116}$. Se trata de un argumento que a estas alturas de la evolución de la disciplina es evidentemente insostenible. Hoy en día se acepta ampliamente que los agentes no estatales pueden vulnerar derechos fundamentales. Por otro lado, un argumento de ese tipo sería contradictorio con cualquier modificación de lege ferenda que se pretenda implementar al Derecho internacional de los derechos humanos, Derecho que, justamente, posee -y debe poseer- un carácter evolutivo que le permita adaptarse con flexibilidad a la realidad vigente. Si una hipótesis concreta de afectación de derechos humanos demanda una respuesta normativa, no hay razón para negar su implementación, siempre que esa respuesta se traduzca en la elaboración de instituciones jurídicas coherentes, que puedan ser aplicadas con márgenes satisfactorios de eficacia y que estén fundamentadas en argumentos razonables. La plasmación de nuevas instituciones jurídicas no puede ser detenida por el respeto ciego a la tradición, más aún si los esquemas tradicionales se han tornado incapaces de proteger los derechos humanos ${ }^{117}$.

Analizados los argumentos de la primera postura, es necesario ahora esbozar los argumentos de la posición favorable a la inclusión de los agentes no estatales. Según esta posición, en la práctica la desaparición no es un delito que viene cometido únicamente por agentes estatales ${ }^{118}$. Ha habido situaciones en que agrupaciones paramilitares y grupos armados de diversa índole han participado en la comisión generalizada y sistemática de desapariciones forzadas. Este importante dato es suficiente para demostrar que la desaparición

\footnotetext{
115 Carrillo (2013), p. 3, argumentando que "la protección de los derechos humanos frente a actores no estatales no supone la desaparición de las obligaciones estatales de respeto y protección" y agregando que "la presencia de responsabilidades no estatales no es una excusa válida que permite a los Estados evadir sus propias obligaciones".

${ }^{116} \mathrm{CDH}$ (2004), párr. 31; CDH (2005), párr. 31.

117 Carrillo (2013), p. 5; Clapham (2006), pp. 33-35, concluyendo que el elemento determinante no es el sujeto obligado, sino el derecho o bien jurídico que se pretende proteger.

118 CDH (2002), párr. 73; CDH (2005), párr. 30; CDH (2006), p. 52, específicamente, la opinión esbozada por la delegación de India. En doctrina Anderson (2007), p. 256; SCOvazzI y Citroni (2007), p. 279. Véase también Asamblea Parlamentaria del Consejo de Europa (2005b), párr. 46.
} 
ha dejado de ser un delito esencialmente estatal ${ }^{119}$. Por lo tanto, desde el punto de vista jurídico habrá que analizar en cada caso concreto las características del agente y la eventual existencia de vínculos con el Estado ${ }^{120}$.

Otro argumento esgrimido por esta posición es de carácter probatorio. Según la opinión del experto independiente Nowak, la impunidad que rodea la comisión de la desaparición forzada dificulta enormemente la prueba de un vínculo de autorización, apoyo o aquiescencia entre un sujeto no estatal y el Estado. En esos casos, el Estado podría ser responsable, aunque el sujeto actor no haya sido uno de sus órganos. Según el experto, este tipo de dificultades probatorias fundamentan la incorporación de agentes no estatales en la tipificación penal interna de la desaparición forzada ${ }^{121}$.

Un último argumento está relacionado con la perspectiva de las víctimas. El sufrimiento que experimentan las víctimas no depende de la tipología de autor que ha cometido la desaparición ${ }^{122}$. Si el fundamento último de los derechos humanos es la dignidad del ser humano es evidente que la aplicación de los mecanismos destinados a su protección debe proceder con independencia del tipo de sujeto que incurre en la violación ${ }^{123}$.

Pese a este evidente desacuerdo entre las delegaciones, se alcanzó una solución de compromiso que quedó reflejada en la versión final del art. 3 de la CIPPDF. Sin embargo, se trata de una solución técnicamente deficiente

\footnotetext{
119 Piénsese en las desapariciones forzadas cometidas por grupos paramilitares en los contextos colombiano y guatemalteco, tratándose en esos casos de agentes no estatales que actúan con la autorización, apoyo o aquiescencia del Estado. Confróntese las siguientes sentencias de la CORTE IDH: Masacre de Mapiripán v. Colombia, de 15 de septiembre de 2005.; Masacre de Pueblo Bello v. Colombia, de 31 de enero de 2006; Masacres de Río Negro v. Guatemala, de 4 de septiembre de 2012; Masacre Plan de Sánchez v. Guatemala, de 29 de abril de 2004; Blake v. Guatemala, de 24 de enero de 1998. Asimismo, piénsese en las desapariciones en que no ha sido posible acreditar la intervención de los agentes no estatales y, pese a ello, se ha condenado al Estado por infracción de los deberes de prevención, investigación y/o sanción. CORTE IDH. González y otras ("Campo Algodonero") v. México, de 16 de noviembre de 2009. TEDH: Kaya v. Turkey, de 28 de marzo de 2000; Koku v. Turkey, de 31 de mayo de 2005; Kurt v. Turkey, judgment, de 25 de mayo de 1998; Osmanoğlu v. Turkey, de 24 de enero de 2008.

120 La naturaleza de los agentes no estatales no siempre es nítida en relación a su eventual vinculación con el aparato estatal, porque dicha relación muchas veces es difuminada. Por lo demás, podría tratarse de una relación que evoluciona o involuciona con el transcurso del tiempo, ya que una organización de este tipo puede nacer al alero del Estado, para luego ir adquiriendo progresivamente independencia o, viceversa, una organización que se genera de manera autónoma podría vincularse en un momento posterior con el poder estatal. Véase VRANCKX (2007), pp. 10-11.

121 CDH (2002), párr. 73.

122 Huhle (2013), p. 23; Scovazzi y Citroni (2007), p. 278; Vermeulen (2011), p. 154; y Ott (2011), p. 23.

123 Carrillo (2013), pp. 4-5, 15, 18 y 20; y Clapham (2010), pp. 563-564.
} 
e intencionadamente ambigua"24. El art. 3 dispone que "[l]os Estados Partes tomarán las medidas apropiadas para investigar sobre las conductas definidas en el artículo 2 que sean obra de personas o grupos de personas que actúen sin la autorización, el apoyo o la aquiescencia del Estado, y para procesar a los responsables" (las cursivas son nuestras). Pese a la redacción ambivalente de esta disposición, es posible extraer al menos dos conclusiones. Primero, los agentes no estatales no se incluyeron entre los sujetos activos de la definición del art. 2. En segundo lugar, sin embargo, los agentes no estatales no quedaron absolutamente excluidos de las disposiciones del tratado, dado que éste impone deberes internacionales a los Estados partes en relación con desapariciones cometidas "sin la autorización, el apoyo o la aquiescencia del Estado"125.

De todos modos, la disposición genera muchas preguntas. Cabe preguntarse si se refiere efectivamente a desapariciones forzadas, dado que evita una referencia expresa a ellas, prefiriendo remitirse a "las conductas definidas en el artículo 2". El art. 2 es el que contempla la definición de la desaparición forzada, considerando como sujeto activos a "agentes del Estado o [...] personas o grupos de personas que actúan con la autorización, el apoyo o la aquiescencia del Estado". ¿Se puede concluir que las "conductas definidas en el artículo 2" cometidas por personas que actúan sin un vínculo estatal son desapariciones forzadas? Si bien, la fórmula remisiva del art. 3 no ha sido la mejor manera de aclarar esta cuestión ${ }^{126}$, es plausible sostener que el objetivo

${ }^{124}$ La propuesta originaria de este artículo puede consultarse en CDH (2004), párr. 35. La aprobación de la redacción actual del texto se fraguó en el quinto período de sesiones del Grupo de Trabajo de Composición Abierta, como consta en CDH (2006), párrs. 12-15. Esta solución de compromiso no dejó satisfechas a todas las delegaciones. Por ejemplo, la delegación de Filipinas declaró que hubiera preferido una mayor atención de la Convención hacia los agentes no estatales y que de acuerdo con su interpretación, no hay obstáculo para que en la tipificación interna se integre a dichos agentes. Confróntese AG (2006); AG (2007), párr. 15; Asamblea Parlamentaria del Consejo de Europa (2012), párr. 6.2.2., alegando que los agentes no estatales deberían haber sido incluidos en la definición.

125 En contra, véase Linghammar (2009), p. 16, para quien los agentes no estatales han sido excluidos del ámbito de aplicación de la Convención.

126 Hubo mucha discusión durante la preparación del tratado sobre la mejor redacción de la disposición. Las expresiones que se barajaron para identificar a los agentes no estatales fueron muchas, entre otras, "organizaciones políticas", "actos de los grupos organizados y de los particulares", "organizaciones o grupos que tienen el control efectivo de una parte del territorio del Estado", "personas que actúan fuera de la autoridad directa o indirecta del Estado", "miembros de organizaciones políticas" y "toda organización, incluida las entidades económicas". Incluso, se propuso obviar toda referencia al sujeto activo en la definición, a fin de obligar a los Estados a tipificar la desaparición cualquiera fuese el autor. En definitiva, se optó por una redacción negativa -"personas o grupos de personas que actúen sin la autorización, el apoyo o la aquiescencia del Estado"- que resulta criticable por su vaguedad. Véase CDH (2004), párrs. 28-29 y 39; CDH (2005), párr. 29. 
de esta norma consiste en imponer a los Estados partes las obligaciones internacionales de investigar y sancionar las desapariciones cometidas por agentes no estatales autónomos que actúan sin la autorización, apoyo o aquiescencia del Estado ${ }^{127}$. Esta conclusión viene reafirmada por la práctica del CED, que ha alentado a los Estados partes "a que incorpore[n] a la legislación nacional las medidas a que se hace referencia en el artículo 3 de la Convención"128.

Sin embargo, parece ser que a juicio del CED habría que distinguir entre la desaparición forzada (art. 2) que puede ser cometida por agentes estatales y agentes no estatales que actúan con la autorización, el apoyo o la aquiescencia del Estado, y "otras conductas análogas" (art. 3) que pueden ser cometidas por agentes no estatales sin vínculo alguno con el Estado ${ }^{129}$. Respecto de la desaparición regirían todas las obligaciones internacionales del tratado, mientras que respecto de las "conductas análogas" sólo se aplicarían las obligaciones de investigar y sancionar ${ }^{130}$. El principal temor del CED para aceptar la plausibilidad de la comisión de las desapariciones por parte de agentes no estatales dice relación con las dificultades que podrían surgir a propósito de las estrategias de registro, investigación, búsqueda y sanción, estrategias que deben ser distintas dependiendo del tipo de conducta ${ }^{131}$.

A pesar de que el CED ha insistido sobre la tesis tradicional de la estatalidad de la desaparición ${ }^{132}$, creemos que la realidad actual del fenómeno obliga a reinterpretar de manera distinta la lectura de los artículos 2 y 3 de la Convención, asumiéndose que este tratado reconoce al menos implícitamente la plausibilidad de la comisión de desapariciones por agentes no estatales ${ }^{133}$. Si no se asume esta conclusión, no sería posible justificar la incorporación del art. 3 a un tratado cuyo objeto específico de regulación es la desaparición forzada. Por ende, si se considera la clasificación de los sujetos activos que

127 Hall y Van den Herik (2016), p. 288.

128 CED (2017), párr. 16.

129 CED (2016), párr. 15. El CED planteó su posición a propósito del art. 165 del Código Penal colombiano, que incluye a los agentes no estatales entre los autores de la desaparición, aunque actúen sin tener vínculo alguno con el Estado.

130 Por ejemplo, el CED (2015), párr. 12, recomendó especificar en un registro sobre personas desaparecidas "si se trata de una desaparición en la que no hayan participado en modo alguno agentes del Estado (art. 3 de la Convención)".

131 CED (2016), párrs. 15-16. Quizás sea plausible especular que al CED le preocupara que las desapariciones cometidas por el Estado o las agrupaciones paramilitares fueron confundidas con los secuestros realizados por las agrupaciones guerrilleras o el crimen organizado.

132 CED (2016), párr. 15.

133 Véase Huhle (2013), pp. 22 y 23. En contra, McCrory (2007), p. 551. 
se ha propuesto en este trabajo, el art. 2 se refiere a los agentes estatales y a los agentes no estatales que actúan con la autorización, apoyo o aquiescencia del Estado, mientras que el artículo 3 se refiere a los agentes no estatales que actúan sin tener una vinculación con el Estado.

A modo de conclusión, Huhle tiene razón cuando sostiene que la CIPPDF "por un lado, sostiene la doctrina ortodoxa según la que las violaciones a los derechos humanos son el privilegio de los Estados. Por otro lado, reconoce que materialmente el mismo acto que constituye una desaparición forzada puede ser y es cometido también por agentes no estatales"134. Sin embargo, la solución de compromiso ha producido como resultado una disposición enrevesada que genera y seguirá generando inevitables dudas interpretativas.

\subsection{La organización política como sujeto activo en el Estatuto de Roma}

Una de las novedades que presentó la definición de la desaparición forzada del ER en relación con el resto de los instrumentos internacionales fue la mención de un agente no estatal como sujeto activo de este delito: la organización política ${ }^{135}$.

El ER define en el art. 7(1) los crímenes de lesa humanidad como aquellos que se comenten "como parte de un ataque generalizado o sistemático contra una población civil y con conocimiento de dicho ataque". Esta definición contiene los elementos contextuales de los crímenes de lesa humanidad. Ahora bien, cuando en el art. 7(2)(a) el ER define el "ataque contra una población civil" como elemento contextual, dispone que se trata de una "línea de conducta que implique la comisión múltiple de actos mencionados en el párrafo 1 contra una población civil, de conformidad con la política de un Estado o de una organización de cometer ese ataque o para promover esa política" (las cursivas son nuestras). Lo que interesa para los fines del presente apartado es que la política que sirve de marco para la comisión de los actos puede ser la de un Estado o la de una "organización", dejando en claro que detrás de dicha política puede estar una organización distinta del Estado. Por otra parte, el ER contiene una segunda mención referida a una organización, ya que al definir la desaparición forzada en el art. 7(2)(i), prescribe que pueden ser sujetos activos de este crimen un Estado o una organización política.

\footnotetext{
134 HuHLe (2013), p. 23.

135 Según algunos autores, la expansión de la autoría se explica porque el ER tiene por objeto perseguir la responsabilidad penal internacional del individuo y no la responsabilidad internacional del Estado. Véase Linghammar (2009), p. 34; Hall y Van den Herik (2016), p. 288.
} 
Por ende, al incorporar el término "organización" en el marco de los elementos contextuales de los crímenes de lesa humanidad, el ER entiende que los integrantes de una agrupación no estatal pueden participar en la comisión de tales delitos. Sin embargo, no existe acuerdo ni en la doctrina ni en la jurisprudencia de la CPI sobre las características que debe tener la organización, pudiendo destacarse dos posturas generales. Por un lado, la Sala de Cuestiones Preliminares (en adelante, SCP) II ha sostenido que la característica definitoria de la organización es su capacidad para llevar a cabo actos que atentan contra valores humanos básicos ${ }^{136}$. Aunque esta capacidad debe ser valorada casuísticamente, en la jurisprudencia de la CPI se ha hecho mención a una lista no exhaustiva de factores que pueden tomarse en consideración; a saber: 1) la presencia de una autoridad, un mando responsable o una estructura jerárquica; 2) la existencia de medios para llevar a cabo un ataque generalizado o sistemático contra la población civil; 3) el control sobre una parte del territorio de un Estado; 4) la constatación del objetivo de cometer actividades delictivas contra la población civil; 5) la manifestación explícita o implícita de atacar la población civil; 6) la pertenencia a un grupo más grande que cumple a su vez algunos de los criterios anteriores ${ }^{137}$.

Sin embargo, el juez Hans-Peter Kaul manifestó en una serie de opiniones disidentes que el elemento definitorio de la organización es su similitud formal, estructural u organizativa con el Estado (State-like organization), planteando una serie de criterios que deberían tenerse en cuenta para valorar esta asimilación; a saber: 1) configurar una colectividad de personas; 2) establecerse y actuar con un objetivo común; 3) desarrollar sus actividades por un periodo de tiempo prolongado; 4) tener un mando responsable y un cierto grado de

\footnotetext{
136 CPI. SCP II. Decision Pursuant to Article 15 of the Rome Statute on the Authorization of an Investigation into the Situation in the Republic of Kenya. ICC-01/09-19, 31 de marzo de 2010, párrs. 90-92. En algunas resoluciones anteriores, la CPI no había profundizado sobre la conceptualización de la organización, aunque había admitido que la política de un ataque podía ser emprendida por una entidad no estatal que tuviere el control sobre una porción de territorio o que tuviere la capacidad de cometer un ataque sistemático y generalizado contra la población civil. Cfr. SCP I. Germain Katanga and Mathieu Ngudjolo Chui, ICC-01/04-01/07-717, 30 de septiembre de 2008, párr. 396; SCP II. Jean-Pierre Bemba Gombo, 15 de junio de 2009, párr. 81. Sin embargo, la tesis de la capacidad para llevar a cabo actos que atentan contra valores humanos básicos ha sido defendida en jurisprudencia posterior a la decisión sobre la autorización de investigación en la situación de la República de Kenya: SCP II. Ruto et al. ICC-01/09-01/11-373, 23 de enero de 2012, párrs. 33 y 184; SCP II. Muthaura et al. ICC-01/09-02/11-382-Red, 23 de enero de 2012, párr. 112.

137 Cfr. CPI, SCP II, Decision Pursuant to Article 15 of the Rome Statute..., ICC-01/09-19, cit., párr. 93; CPI, SCP II, Ruto et al., ICC-01/09-01/11-373, cit., párr. 185; CPI. SCP III. Corrigendum to "Decision Pursuant to Article 15 of the Rome Statute on the Authorisation of an Investigation into the Situation in the Republic of Côte d'Ivoire", ICC-02/11-14-Corr, 15 de noviembre de 2011, párr. 46; CPI. SCP I. Katanga and Ngudjolo. ICC-01/04-01/07-717, 30 de septiembre de 2008, párr. 396.
} 
estructura jerárquica, incluyendo, como mínimo, algún tipo de nivel político; 5) tener la capacidad de imponer la política a sus miembros y de sancionarlos; y 6) tener la capacidad y los medios disponibles para realizar ataques a gran escala contra la población civil ${ }^{138}$.

La duplicidad de respuestas posibles sobre la naturaleza de la "organización" que ha surgido de la jurisprudencia de la CPI, ha dado lugar a un interesante y complejo debate académico que ha enfrentado una interpretación amplia contra una interpretación más restringida. La cantidad, diversidad y complejidad de los argumentos esgrimidos por cada posición no puede ser abordada en este trabajo ${ }^{139}$, pero son interesantes algunas apreciaciones generales de Ambos. En primer lugar, el profesor alemán destaca que no hay mucha diferencia entre los criterios de la SCP II para valorar la capacidad de una organización para afectar valores humanos básicos y los criterios del juez Kaul para identificar una organización asimilable a un Estado. Más bien, la toma de posición en este debate depende del enfoque personal que se adopte respecto de la naturaleza del Derecho penal internacional, porque si se pretende que esta disciplina se utilice como una herramienta para una protección extendida y generalizada de los derechos humanos, lo lógico sería optar por interpretaciones más amplias, mientras que si se defiende la aplicación de los principios liberales clásicos del Derecho penal y la lógica interestatal tradicional del Derecho internacional público, es más consecuente adherirse a las interpretaciones más restringidas ${ }^{140}$. En nuestra opinión, la primera de las dos posiciones parece ser más convincente por ser más acorde con la protección de los derechos fundamentales y adoptar un enfoque centrado en las víctimas ${ }^{141}$.

Ahora bien, en relación con la "organización política" como elemento conceptual de la desaparición forzada, cabe señalar que hasta la fecha el

\footnotetext{
${ }^{138}$ Confróntese las siguientes opiniones disidentes esgrimidas en resoluciones de la SCPII de la CPI: Decision Pursuant to Article 15 of the Rome Statute..., ICC-01/09-19, cit., Dissenting Opinion by Judge KauL, párrs. 51-55; Ruto et al., ICC-01/09-01/11-373, cit., Dissenting Opinion by Judge KauL, párrs. 8-9 y 13; Muthaura et al., ICC-01/09-02/11-382-Red, cit., Dissenting Opinion by Judge KaUL, párrs. 7-8 y 20.

139 Para una síntesis de los argumentos a favor de una interpretación amplia, véase SADAT (2013), pp. 334-377. Por el contrario, para un resumen de los argumentos favorables a una interpretación estricta, véase KRESS (2010), pp. 855-873.

140 Ambos (2014), t. II, pp. 74-75.

141 Entre los partidarios del enfoque amplio, confróntese Hall y Ambos (2016), pp. 249-250; WerLE y BURGHARDT (2012), pp. 1166-1168. Entre los partidarios de un enfoque restringido, defendiento que la organización debe ser asimilable a un Estado (State-like organization) cfr. Aмвоs (2014), t. II, p. 72; Giorgou (2013), pp. 1018-1020; Stahn (2014), p. 818.
} 
significado de este sintagma no ha sido tratado en la jurisprudencia de la $\mathrm{CPI}$. Desde luego, cabe preguntarse si existe una conexión entre la noción general de "organización" y el concepto más específico de "organización política". Durante los trabajos preparatorios del Estatuto se decidió incluir la organización política como sujeto activo de la desaparición forzada, con el argumento de que en la realidad este delito está siendo cometido también por agentes no estatales ${ }^{142}$, aunque esta incorporación no ha estado exenta de críticas $^{143}$. En cuanto a la interpretación de lo que es una "organización política" existen dos posiciones. Algunos autores son partidarios de una interpretación amplia ${ }^{144}$, mientras que otros apoyan una noción más restringida, exigiendo que la organización cumpla con ciertas funciones similares a las del Estado, tomando en consideración que sólo el Estado y las entidades no estatales que se le asimilen pueden tener la capacidad para asegurar los recursos procesales pertinentes para evitar la denegación de información como conducta constitutiva de la desaparición ${ }^{145}$. Cabe recordar que asumir que agentes no estatales pueden ser penalmente responsables por la comisión de desapariciones forzadas obliga a resolver algunos dilemas dogmáticos analizados con anterioridad.

\section{La sustracción a la protección de la ley}

Todos los instrumentos internacionales que han consagrado una definición de la desaparición forzada han hecho referencia a la sustracción a la protección de ley. En términos generales, según Andreu-Guzmán consiste en "el efecto de suspender el disfrute de todos los derechos de la persona desaparecida y de colocar a la víctima en una situación de completa indefensión"146. En términos más concretos, remover a una persona de la protección del Derecho significa impedirle que haga valer las garantías procesales que establece la

${ }^{142}$ Giorgou (2013), p. 1008, n. 26.

143 Giorgou (2013), pp. 1010-1015; y Anderson (2007), p. 256.

144 Pérez (2006), p. 18, considerando que la organización política abarca cualquier grupo de personas que persigue fines políticos, por ejemplo, un movimiento de liberación nacional, grupos guerrilleros, pueblos beligerantes e incluso terroristas o partidos políticos; Modolél (2010), p. 206, para quien la organización política es toda organización que actúa contra el poder constituido; ВоОт (2002), p. 527, sosteniendo que los particulares en general pueden ser autores de desapariciones forzadas.

145 Амвоs (2014), t. II, p. 111; Амвоs у Вӧнм (2009), pp. 246-248; Gıorgou (2013), pp. 1015-1020; Ott (2011), p. 25; Hall y VAn den Herik (2016), p. 288.

146 ANDREu-GuZmán (2001), p. 75: "the effect of suspending enjoyment of all of the rights of the disappeared person and placing the victim in a situation of complete defenselessness". 
ley ${ }^{147}$. En opinión del CED, "un detenido queda sustraído a la protección de la ley cuando, como consecuencia de la desaparición, se impide ejercitar los recursos que la legislación del Estado parte pone a su disposición"148.

La sustracción a la protección de la ley se produce a consecuencia de la denegación de información, ya que la persona desaparecida, al estar sometida a un régimen ilegal de privación de libertad que suele ser secreta e incomunicada, está fáctica y jurídicamente inhabilitada para valerse de las garantías procesales consagradas en favor del detenido. Por su lado, aunque los familiares u otras personas cercanas al desaparecido puedan hacer valer los recursos procesales disponibles en los ordenamientos jurídicos internos, su la eficacia será obstaculizada por la ausencia de información sobre la persona desaparecida, lo que dificultará hallarla, revisar la juridicidad de su detención y solicitar su puesta en libertad.

Para un estudio detallado de este elemento, el epígrafe será dividido en dos secciones. La primera analizará la naturaleza jurídica de la sustracción a la protección de la ley, a fin de determinar si se trata de un elemento conceptual de la desaparición forzada o de una consecuencia derivada de la configuración de los elementos anteriores. La segunda sección analizará algunas exigencias adicionales anexadas a este elemento en la definición del ER.

\subsection{La sustracción a la protección de la ley: ¿elemento o consecuencia?}

Durante los travaux préparatoires de la CIPPDF se debatió sobre la naturaleza jurídica de la sustracción a la protección de la ley ${ }^{149}$. Mientras algunas delegaciones ( $v$. gr. Reino Unido, China y Egipto) consideraban que se trataba de un elemento constitutivo de la definición ${ }^{150}$, otras ( $v$. gr. Argentina) entendían que se trataba de una consecuencia producida a raíz de la configuración del resto de los elementos definitorios ${ }^{151}$. El debate no es baladí, sobre todo de cara a la obligación internacional de los Estados de tipificar la desaparición en el Derecho interno ${ }^{152}$. La discusión fue zanjada por el Presidente del

147 Воот (2002), p. 527; y Отт (2011), p. 27.

148 CED, Yrusta v. Argentina, cit., párr. 10.4.

${ }^{149}$ Cabe señalar que el primer proyecto de 1998 de la CIPPDF no se refería a la sustracción a la protección de la ley. Véase Subcomisión de Prevención de Discriminaciones y Protección a las Minorías (1998), Anexo, art. 1.

${ }^{150} \mathrm{CDH}$ (2006), párr. 92. En los debates finales, muchas delegaciones interpretaron que se trataba de un elemento conceptual: AG (2007), párrs. 13 y 19; AG (2006b), p. 2; AG (2006).

151 CDH (2005), párr. 25; CDH (2006), párr. 91.

152 VibHute (2008), p. 302. 
Grupo de Trabajo, quien propuso una fórmula de compromiso según la cual la sustracción de la protección de la ley se incluyera en la definición de la desaparición, pero como una "ambigüedad constructiva" que otorgare a los Estados una libertad interpretativa para la implementación del tratado ${ }^{153}$.

Para Rodley y Pollard esta solución es muy criticable, porque debería haberse evitado dejar a la discrecionalidad de los Estados una cuestión tan determinante como la delimitación conceptual de la desaparición. Estos autores han esbozado algunas interpretaciones posibles de la solución de compromiso. Según una primera interpretación, los Estados podrían decidir si incorporan la sustracción en la tipificación interna. En cambio, una segunda interpretación sugiere que los Estados tienen la obligación de incorporar la sustracción en la definición, pero con un margen de discrecionalidad a la hora de determinar su calificación como elemento objetivo o subjetivo. Dicho con otras palabras, esta segunda interpretación implica que la sustracción pueda ser incorporada como una situación de hecho que afecta a la persona privada de libertad o como una exigencia específica vinculada con la culpabilidad del autor.

La mayoría de la doctrina considera que la sustracción a la protección de la ley es una consecuencia que se genera por la concurrencia del resto de los elementos conceptuales, aunque no se suele ahondar en la fundamentación de esta posición ${ }^{154}$. En cambio, Rodley y Pollard creen que la mejor manera de solucionar este enrevesado asunto hermenéutico estriba en considerar la sustracción como un elemento objetivo que consiste en una situación de hecho. De esa manera, se sortean eventuales problemas probatorios relacionados con la subjetividad del autor y se evitará confundir la desaparición forzada con las detenciones arbitrarias o ilegales, porque de no exigirse la sustracción a la protección de la ley sería dificultoso diferenciar ambos ilícitos ${ }^{155}$. Por su parte, el CED ha criticado las tipificaciones penales que adicionan un elemento subjetivo intencional no incluido en la definición de la CPPDF ${ }^{156}$.

\footnotetext{
${ }^{153}$ CDH (2005), párr. 23; CDH (2006), párr. 23.

154 Calvet Martínez (2009), p. 521; Capellà I Rolg (2006), p. 271; Pérez (2006), pp. 11, 16 y 19; SCovazzi y Citroni (2007), p. 273; MAnero (2012), pp. 109-110; Stevens (2010), p. 377; Anderson (2007), p. 273, argumentan que la redacción de la definición permite a los Estados incorporar la sustracción como un elemento conceptual, pero en su opinión no sería prudente hacerlo, dado que la opinión dominante en el seno del Grupo de Trabajo y en las asociaciones de familiares desaparecidos era favorable a su consideración como una consecuencia. También el GTDFI (2008), párr. 5, considera que es una consecuencia.

155 Rodley y Pollard (2009), pp. 336-337.

${ }^{156}$ CED (2013), párrs. 12-13, a propósito de la tipificación penal en Francia.
} 
La objetivación de la sustracción a la protección de la ley parece ser la solución más razonable. En la práctica, la sustracción a la protección de la ley se traduce en la consecuencia generada por la concurrencia del resto de los elementos definitorios, especialmente, la denegación de información, en cuanto se trata de la conducta que imposibilita el ejercicio de las garantías procesales. Por el contrario, es rechazable una interpretación subjetiva, porque obligaría a probar una intención específica del autor consistente en el conocimiento o la voluntad de situar a la víctima fuera de la órbita de protección del Derecho. La prueba de un elemento subjetivo de esa naturaleza sería extremadamente compleja.

Como apunte crítico, debe señalarse que el problema de la naturaleza jurídica de la sustracción a la protección de la ley no fue resuelto adecuadamente por los redactores de la Convención. Se puede entender la finalidad política de la solución de "ambigüedad constructiva", pero jurídicamente se dejó abierta una puerta discrecional demasiado ancha que puede incidir negativamente en el proceso de tipificación interna de la desaparición forzada, promoviendo la construcción de tipos penales demasiado exigentes en el plano subjetivo, poco comprensibles, difícilmente aplicables en la práctica y alejados de la realidad ${ }^{157}$. Afortunadamente, en su práctica reciente el CED ha considerado que la sustracción a la protección de la ley es una consecuencia y no un elemento definitorio ${ }^{158}$, asumiendo la posición que se ha defendido en este apartado.

\subsection{Las exigencias adicionales incorporadas en la definición del Estatuto de Roma}

La definición del ER contempla la sustracción a la protección de la ley anexando exigencias de carácter temporal e intencional. Ambas serán analizadas separadamente.

\footnotetext{
${ }^{157}$ El resto de los instrumentos internacionales sobre la desaparición tampoco han zanjado adecuadamente el problema. La definición de la CIDFP alude únicamente al "ejercicio de los recursos legales y de las garantías procesales pertinentes". La interpretación literal de esta expresión puede conducir a resultados absurdos, porque en la práctica la situación de indefensión jurídica de la persona desaparecida puede generarse por una pluralidad de motivos y no sólo por la falta de acceso a los recursos procesales. De hecho, en muchos contextos los familiares tienen un acceso meramente formal a los recursos, dado que el contexto hace que su ejercicio resulte ineficaz. Dado que el tópico ha sido regulado de una manera muy restringida en la CIDFP, algunos autores prefieren la fórmula más amplia de la CIPPDF. Véase Claude (2010), p. 429; Pérez (2006), p. 13.

${ }^{158}$ CED, Yrusta v. Argentina, cit., párr. 10.4; CED (2014), párrs. 13-14; CED (2013), párrs. 12-13. Confróntese la opinión del GTDFI en Consejo de Derechos Humanos (2010), párr. 38. En el mismo sentido, CoRte IDH. Osorio Rivera y familiares v. Perú, de 26 de noviembre de 2013, párr. 170.
} 


\subsubsection{La exigencia temporal}

EI ER exige que la sustracción a la protección de la ley tenga lugar "por un período prolongado". Sin duda es un requisito problemático que resulta criticable desde un enfoque práctico y realista. No son pocos los casos de desapariciones forzadas en que la víctima es ejecutada al cabo de un breve lapso contado desde la privación de libertad, con lo cual la exigibilidad de un requisito temporal podría impedir que casos de esa naturaleza sean tratados como desapariciones forzadas ${ }^{159}$. Tienen razón Scovazzi y Citroni cuando argumentan que "una vez que el delito es cometido, su existencia no se altera por el hecho de que dure unas pocas horas o varios años"160. Por ejemplo, en el caso Yrusta v. Argentina, el CED concluyó que se había producido una desaparición por el hecho de que la autoridad competente denegó la información sobre un detenido durante un plazo de siete días ${ }^{161}$.

Quizás el debate que se suscitó durante la negociación de la CIPPDF puede servir de ayuda para interpretar el contenido de una exigencia temporal. En los travaux préparatoires se propuso incorporar un requisito temporal, pero no hubo unanimidad sobre su interpretación. Las delegaciones favorables consideraban que en todas las desapariciones forzadas transcurre "algún tiempo entre la detención y la notificación del encarcelamiento"162. Aunque en la desaparición no se produce necesariamente una "notificación del encarcelamiento", cabe inferir que esta tesis entiende que en toda desaparición debe transcurrir un largo período de tiempo desde que se pierde el rastro de la persona desaparecida hasta que se obtenga alguna información sobre lo ocurrido. Por su parte, otras delegaciones sostenían que la expresión "período prolongado" era imprecisa y flexibiliza el umbral de protección, con lo cual desde la perspectiva de las garantías procesales del detenido era preferible no dificultar la interpretación de la definición ${ }^{163}$. Por estas razones el elemento temporal no fue incorporado en la definición de la CIPPDF.

\footnotetext{
159 Hall y Van den Herik (2016), p. 290; Linghammar (2009), pp. 13-14; McCrory (2007), p. 552; Modoletl GonzÁlez (2010), p. 204; y GTDFI (2008), párrs. 9-10. Por ejemplo, en el caso del TEDH. Kukayev v. Russia, de 15 de noviembre de 2007, párrs. 90-91 y 107-108, la persona desaparecida fue ejecutada el mismo día de su detención, de modo que el Tribunal consideró que se trataba de una desaparición forzada.

160 Scovazzi y Citroni (2007), p. 276: "once the offence is committed, its existence is not altered by the fact that it lasts a few hours or several years".

161 CED, Yrusta v. Argentina, cit., párr. 10.2.

${ }^{162} \mathrm{CDH}$ (2004), párr. 22.

${ }^{163}$ CDH (2004), párr. 23. Confróntese Comisión INTERnACIONAL DE JurISTAS (2015), pp. 18-19.
} 


\subsubsection{La exigencia de intencionalidad}

De acuerdo con el ER, la desaparición debe realizarse con la "intención" de sustraer a la víctima de la protección de la ley. Siguiendo un análisis similar al realizado en el punto anterior, cabe reseñar la discusión que tuvo lugar sobre la intencionalidad durante la negociación de la CIPPDF. Las apreciaciones sobre este requisito no fueron técnicamente rigurosas, probablemente porque se trata de una cuestión penal técnicamente compleja vinculada con la dimensión subjetiva del delito ${ }^{164}$. Algunas delegaciones estimaban que la intencionalidad era un requisito esencial de la desaparición ( $v$. gr. Estados Unidos) ${ }^{165}$ y que era necesaria para diferenciarla de otros delitos ${ }^{166}$. Por el contrario, otras delegaciones se oponían a la incorporación de la intencionalidad, atendido a la dificultad de la prueba de una exigencia subjetiva de esa índole ${ }^{167}$. Según Nowak, "los autores sólo tienen por lo general la intención de secuestrar a la víctima sin dejar rastro alguno, a fin de llevarla a un lugar secreto con el propósito de interrogarla, intimidarla, torturarla o sencillamente asesinarla secretamente ${ }^{\prime 168}$. Por esta razón, la intencionalidad de la desaparición está implícita en la definición ${ }^{169}$ o se trata de un problema de Derecho interno. En definitiva, la definición de la CPPDF no contempla una exigencia específica de intencionalidad.

Entonces, ¿qué entiende el ER cuando alude a la intención? Cabe recordar que este tratado regula de manera general el aspecto subjetivo de los delitos de competencia de la CPI en el art. $30^{170}$, aunque algunos crímenes específicos contemplan requisitos subjetivos adicionales ${ }^{171}$, tal como ocurre con la desaparición. A su vez, los EC explican el aspecto subjetivo de este crimen ${ }^{172}$.

\footnotetext{
164 Subcomisión de Prevención de Discriminaciones y Protección a las Minorías (1998), párr. 25; CDH (2003), párr. 40. De conformidad con estas fuentes, algunas delegaciones plantearon que el autor debía actuar sabiendo que su conducta formaba parte de un ataque sistemático y generalizado, olvidando que la desaparición forzada no siempre se configura en el marco contextual de los crímenes de lesa humanidad.

165 CDH (2004), párrs. 24 y 26; AG (2007), párr. 12; Consejo de Derechos Humanos (2007), Annex, p. 2.

${ }^{166} \mathrm{CDH}$ (2005), párr. 24.

167 CDH (2004), párr. 25; CDH (2005), párr. 25.

168 CDH (2002), cit., párr. 74. Confróntese Asamblea Parlamentaria del Consejo de Europa (2005), párr. 47. En doctrina: ANDERSOn (2007), p 271; Linghammar (2009), pp. 14-15; y Rodley y Pollard (2009), p. 337.

${ }^{169} \mathrm{CDH}$ (2004), párr. 25; CDH (2006), párr. 96.

170 Para un análisis del objeto del dolo en relación con el ER, véase AmBOs (2005), pp. 401-406.

171 Амвоs (2005), pp. 388-389.

172 Sadat (2002), pp. 140-141.
} 
En cuanto al elemento cognitivo del dolo, su contenido varía en atención a cada una de las conductas constitutivas. Respecto de la privación de libertad, se exige "[q] ue el autor haya sido consciente de que: a) Tal aprehensión, detención o secuestro sería seguido en el curso normal de los acontecimientos de una negativa a reconocer la privación de libertad o a dar información sobre la suerte o el paradero de esa persona o personas"173. Por su parte, en cuanto a la denegación de información se dispone "[q]ue el autor haya sido consciente de que: b) Tal negativa estuvo precedida o acompañada de esa privación de libertad"174.

A luz de lo anterior, queda por interpretar el sentido de la "intención" en la definición de la desaparición del ER ${ }^{175}$. Según Hall y Van Den Herik, la sustracción a la protección de la ley es una consecuencia de la denegación de información y la intención de sustraer a la víctima a la protección de la ley está implícita en dicha conducta, siendo innecesario acreditar una intencionalidad más específica relacionada con la sustracción. La realidad de la desaparición y su modus operandi reflejan de manera evidente la intención de privar a la víctima de toda protección jurídica, siendo improcedente acreditar otros elementos subjetivos ${ }^{176}$. Sin duda, se trata de una interpretación adecuada.

Por su parte, Modolell González considera que la definición del ER contempla un elemento subjetivo del injusto, esto es, un fin abarcado por la intención del autor, pero cuya concreción no se requiere para la configuración del delito ${ }^{177}$. Otros autores, como Werle, Ambos y Böhm, creen que se trata de un dolo específico o de un dolo más intenso ${ }^{178}$.

Ahora bien, exigir copulativamente una exigencia de intencionalidad y temporalidad, puede generar más complicaciones, porque se podría interpretar

\footnotetext{
173 EC, cit., art. 7(1)(i), elemento 3(a). WiTSCHEL y RüCKERT (1999), p. 103, estiman que este requisito es adecuado, porque permite eximir de culpabilidad a personas que hayan participado de buena fe en la privación de libertad de la víctima y agregan que el dolo se configura aun cuando el autor no conoce la existencia de una conducta denegatoria posterior, bastando que la consciencia de que en el curso normal de los acontecimientos existe la probabilidad de que se deniegue la información sobre la víctima

174 EC, cit., art. 7(1)(i), elemento 3(b). Según Oтт (2011), pp. 182-183, ambas conductas deben ser realizadas intencionadamente y el autor debe tener conocimiento e intención sobre la autorización, apoyo o aquiescencia prestados por el Estado u la organización política.

175 Crítica su incorporación Anderson (2007), p. 259. Confróntese CDH (2002), párr. 74.

176 Hall y Van den Herik (2016), pp. 289-290 y 292. Concuerda Ott (2011), pp. 185-186.

177 Modolell (2009), pp. 189-190; Modolell (2010), p. 204; Corte IDH, Gómez Palomino v. Perú, cit., voto concurrente del juez Sergio García Ramírez, párr. 23.

178 Амвоs (2014), t. II, pp. 112-113; Ambos (2005), pp. 427-428; Амвоs у ВÖHm (2009), p. 250; WerLe (2011), p. 531.
} 
que el elemento temporal debería estar cubierto por el aspecto volitivo del dolo. En ese caso debería acreditarse que el autor no sólo tuvo la intención de sustraer a la víctima a la protección de la ley, sino que quiso hacerlo por un período prolongado de tiempo. Una interpretación de ese tipo debe ser rechazada. Si la prueba aislada de cada uno de estos componentes es difícil, la prueba conjunta de ambos bordearía los márgenes de la imposibilidad. Además, una interpretación de ese tipo conduciría a resultados absurdos, porque si hubiera un autor que sólo tiene intención de sustraer a la víctima a la protección de la ley por unas pocas horas o días, no podría ser responsabilizado dado que su dolo no abarcaría la exigencia temporal ${ }^{179}$.

En vista de todas estas complicaciones técnicas, una interpretación demasiado formalista de la "intención" puede conducir a una aplicación restringida del tipo ${ }^{180}$, sobre todo si se tiene en consideración la dificultad de acreditar un elemento subjetivo de esta naturaleza ${ }^{181}$. Sin duda, las diferencias conceptuales contenidas en la definición de la desaparición forzada en el ER en relación con el resto de los instrumentos internacionales, no beneficia la consolidación de dicha definición en términos consuetudinarios ${ }^{182}$. De todos modos, habrá que esperar cómo se posiciona la CPI ante esta problemática en su jurisprudencia específica sobre la desaparición, esperando que adopte soluciones racionales que no restrinjan exageradamente el ámbito de aplicación del tipo. Cabe recordar, además, que en el ER están tipificados los crímenes internacionales de mayor gravedad y eventualmente, podría ser un contrasentido interpretar los tipos de una manera muy formalista, siendo preferible una interpretación de corte más teleológica ${ }^{183}$. En el intertanto, el GTDFI ha recomendado a los Estados interpretar la definición del ER en los términos del art. 2 de la CIPPDF $^{184}$, esto es, sin incorporar estas exigencias adicionales.

\section{Conclusiones}

Con base en todo lo que se ha expuesto, es plausible proyectar una serie de conclusiones sobre la definición de la desaparición forzada en el Derecho internacional de los derechos humanos:

\footnotetext{
179 Scovazzi y Citroni (2007), pp. 275-276.

180 Linghammar (1999), pp. 31-32.

181 COMISIÓN INTERNACIONAL DE JURISTAS (2015), p. 18.

182 Hall y Van den Herik (2016), p. 286.

183 A favor de la interpretación teleológica del ER, véase SADAT (2013), pp. 371-372.

184 Consejo de Derechos Humanos (2010), párr. 15.
} 
1. La definición de la desaparición forzada está integrada por tres elementos: la privación de libertad, la denegación de información y el sujeto activo. La sustracción a la protección de la ley, en cambio, es una consecuencia de los elementos anteriores.

2. La privación de libertad es una de las conductas esenciales de la desaparición forzada. Generalmente, se realiza de una manera ilícita, mediante el secuestro o la detención ilegal. Sin embargo, es posible que la privación de libertad sea legal ab initio. Para que en este último caso se configure una desaparición forzada, es necesario que, en un momento posterior, la privación de libertad se torne ilegal. Esta consecuencia, en principio, se produce cuando se deniega la información sobre la víctima.

3. La denegación de información es una conducta esencial y el elemento conceptual distintivo de la desaparición forzada, básicamente, porque permite diferenciarla de otros ilícitos. Su contenido se refiere a la suerte y paradero de la víctima. La concesión de la información sobre la persona privada de libertad debe realizarse sin requerimiento previo y dentro de un breve plazo que, preferiblemente, no exceda las cuarenta y ocho horas.

4. Tradicionalmente, la desaparición forzada ha sido considerada un delito estatal, pero la Convención Internacional y el ER aceptan la posibilidad de que agentes no estatales puedan cometer este delito, a pesar de las ambigüedades interpretativas que dejan irresueltas. En este trabajo se ha clasificado al autor de la desaparición sobre la base de lo dispuesto en los diferentes instrumentos internacionales específicamente dedicados a la desaparición. Así, se ha distinguido entre agentes estatales y no estatales, atendido a su pertenencia a la estructura orgánica del Estado. A su vez, entre los agentes no estatales se ha diferenciado los que actúan con la autorización, el apoyo o la aquiescencia del Estado y aquellos que actúan sin tener vínculo alguno con el aparato estatal.

Sin embargo, la fórmula adoptada por la CIPPDF es el resultado de un compromiso adoptado entre diferentes posturas antagónicas defendidas a lo largo de los trabajos preparatorios. Se trata de una fórmula ambigua que genera varios problemas interpretativos. En este trabajo se ha defendido una interpretación amplia de acuerdo con la cual el ámbito de aplicación de la Convención Internacional incluye hipótesis de desapariciones ejecutadas por agentes no estatales. No obstante, no está claro si la Convención pretende que todas las obligaciones consagradas en ella sean aplicables al Estado con independencia de la categoría de agente que comete la desaparición o si sólo algunas de dichas obligaciones son procedentes cuando el autor es un agente no estatal. Hasta el momento, el CED ha diferenciado claramente las desapariciones forzadas cometidas por agentes estatales o con la autorización, 
apoyo y aquiescencia del Estado de otras "conductas análogas" cometidas por agentes no estatales a las que sólo se aplicarían las obligaciones de investigar y sancionar.

Por su parte, el ER contempla la organización política entre los sujetos activos de la desaparición. Sin embargo, el problema estriba en identificar a qué sujetos se refiere este texto normativo. Según una primera postura, debe tratarse de sujetos similares o asimilables al Estado (State-like organization), mientras que una segunda posición maneja un concepto más amplio que incluye cualquier organización que persigue una finalidad política.

5. La sustracción a la protección de la ley es una consecuencia que se produce a raíz de la configuración del resto de los elementos definitorios y que consiste en la desprotección jurídica a la que es sometida la persona desaparecida. Tratándose de una consecuencia es inapropiado exigir la anexión de elementos conceptuales temporales o subjetivos adicionales, en cuanto dificultarían irrazonablemente la prueba del delito y porque no se justifican en relación con la realidad de la práctica de la desaparición forzada.

\section{BibLIOGRAFÍA CONSULTADA}

Alexy, Robert (2008): Teoría de los Derechos Fundamentales. 2a ed. (traducc. Carlos Bernal Pulido, Madrid, Centros de Estudios Políticos y Constitucionales).

Alston, Philip (2005): "The 'Non-a-Cat' Syndrome: Can the International Human Rights Regime Accommodate Non-State Actors?", en: Alston, Philip (editor), Non-State Actors and Human Rights (Oxford, Oxford University Press).

Amвos, Kai (2005): La Parte General del Derecho Penal Internacional. Bases para una Elaboración Dogmática (traducc. Ezequiel Malarino, Bogotá, Ducker \& Humboldt-Konrad Adenauer Stiftung-Temis).

Амвоs, Kai (2014): Treatise on International Criminal Law (Oxford, Oxford University Press).

Амвоs, Kai у Böнм, María Laura (2009): "La desaparición forzada de personas como tipo penal autónomo. Análisis comparado internacional y propuesta legislativa", en: Ambos, Kai y Correa, Juliana (coordinadores), Desapariciones forzadas de personas. Análisis comparado e internacional (Bogotá, Temis), pp. 195-255.

Anderson, Kirsten (2007): "How effective is the 'International Convention for the Protection of all Persons from Enforced Disappearances' likely to be in Holding Individuals Criminally Responsible for Acts of Enforced Disappearances?", en: Melbourne Journal of International Law (Vol. 7), pp. 247-277. 
Andreu-Guzmán, Federico (2001): "The Draft International Convention on the Protection of All Persons from Forced Disappearance", en: The Review (International Commission of Jurists) ( $\mathrm{N}^{\circ}$ 62-63), pp. 73-106.

Bоoт, Machteld (2002): Genocide, Crimes against Humanity, War Crimes.

Nullum Crimen Sine Lege and Subject Matter Jurisdiction of the International Criminal Court (Antwerpen-Oxford-New York, Intersentia).

Börzel, Tanja A. y RiSSE, Thomas (2013): "Human Rights in Areas of Limited Statehood: the New Agenda", en: A.A. V.V., The Persistent Power of Human Rights: from Commitment to Compliance (Cambridge, Cambridge University Press).

Brody, Reed (1991): "The United Nations Creates a Working Group on Arbitrary Detention", en: American Journal of International Law (Vol. 85), pp. 709-715.

Calvet Martínez, Elisenda (2009): "The International Convention for the Protection of all Persons from Enforced Disappearances", en: Gómez Isa, Felipe y De Feyter, Koen (editores), International Human Rights Law in a Global Context (Bilbao, University of Deusto), pp. 515-553.

Capellà I Roıg, Margalida (2006): "Las 'desapariciones forzadas' en España durante la guerra civil y el franquismo: violaciones y crímenes de Derecho internacional sin reparación ni castigo", en: Soroeta Liceras, Juan (editor), Conflictos y protección de derechos humanos en el orden internacional, Cursos de Derechos Humanos de Donostia-San Sebastián (Bilbao, Universidad del País Vasco), Vol. VI, pp. 265-301.

Carrillo Santarelli, Nicolás (2013): "La protección y promoción de los derechos humanos frente a violaciones no estatales por los órganos internacionales", en: Revista Electrónica de Estudios Internacionales ( No 26), pp. 1-21.

Casadevall, Josep (2012): El Convenio Europeo de Derechos Humanos, el Tribunal de Estrasburgo y su jurisprudencia (Valencia, Tirant lo Blanch).

Clapham, Andrew (2006): Human Rights Obligations of Non-State Actors (Oxford, Oxford University Press).

Clapham, Andrew (2010): "Non-State Actors", en: Moeckli, Daniel, Shah, Sangeeta y Sivakumaran, Sandesh (editores), International Human Rights Law (Oxford, Oxford University Press), pp. 561-582.

Claude, Ophelia (2010): "A Comparative Approach to Enforced Disappearances in the Inter-American Court of Human Rights and the European Court of Human Rights Jurisprudence", en: Intercultural Human Rights Law Review (Vol. 5), pp. 407-462. 
Costı, Alberto (2002): "Problems with Current International and National Practices Concerning Extraterritorial Abductions", en: Yearbook of the New Zealand Association for Comparative Law ( $\mathrm{N}^{\circ}$ 8), pp. 57-99.

Courtney, Jocelyn (2010): "Enforced Disappearances in Colombia: A Plea for Synergy between the Courts", en: International Criminal Law Review (Vol. 10, № 5), pp. 679-711.

CRYer, Robert et al. (2010): An Introduction to International Criminal Law and Procedure, $2^{\text {a }}$ ed. (Cambridge, Cambridge University Press).

Cury UrzúA, Enrique (2005): Derecho penal. Parte General, 8a ed. (Santiago. Pontifica Universidad Católica de Chile).

Diez-Bacalso, Mary Aileen (2007): "A Convention Protecting Persons from Enforced Disappearances-An Imperative", en: Asian Federation against Involuntary Disappearance. Disponible en: http://afad-online.org/voice/ may_05/internationallobby.htm [Visitado el 17.11.2017].

Esposito, Andreana; Gentile, Gianluca, y Traspasso, María Teresa (2006): "I crimini contro I'umanitá", en: Lattanzi, Giorgio y Monetti, Vito (coordinadores), La Corte Penale Internazionale. Organi-Competenza-Reati-Processo (Milano, Giuffré), pp. 599-756.

Fernández Neira, Karinna (2010): "Breve análisis de la jurisprudencia chilena, en relación a las graves violaciones a los derechos humanos cometidos durante la dictadura militar", en: Estudios Constitucionales (Año 8, № 1), pp. 467-488.

FINUCANE, Brian (2010): "Enforced Disappearance as a Crime under International Law: A Neglected Origin in the Laws of War", en: The Yale Journal of International Law (Vol. 35), pp. 171-197.

FleCK, Dieter (2003): "Humanitarian Protection against Non-State Actors", en: A.A. V.V., Verhandeln für den Frieden-Negotiating for Peace: Liber Amicorum Tono Eitel (Berlín, Springer).

Galain Palermo, Pablo (2009): “Uruguay", en: Ambos, Kai y Correa, Juliana (coordinadores), Desapariciones forzada de personas. Análisis comparado e internacional (Bogotá, Temis), pp. 135-175.

Giorgou, Irena (2013): "State Involvement in the Perpetration of Enforced Disappearance and the Rome Statute", en: Journal of International Criminal Justice (Vol. 11), pp. 1001-1021.

Guzmán Dalbora, José Luis (2009): "Chile", en: Ambos, Kai y Correa, Juliana (coords.). Desapariciones forzadas de personas. Análisis comparado e internacional, (Bogotá, Temis), pp. 53-73. 
Hall, Christopher K. y Ambos, Kai (2016): "Article 7. II. Paragraph 2: Definitions of crimes or their elements. 1. 'Attack", en: Triffterer, Otto y Ambos, Kai, The Rome Statute of the International Criminal Court. A Commentary, $3^{\text {a }}$ ed. (München, Beck-Hart-Nomos), pp. 242-250.

Hill-Cawthorne, Lawrence (2016): Detention in Non-International Armed Conflict. (Oxford, Oxford University Press).

HuHle, Reiner (2013). "Non-State Actors of Enforced Disappearance and the UN Convention for the Protection of All Persons from Enforced Disappearance", en: Humanitäres Völkerrecht, (Vol. 26), pp. 21-26.

Kyriakou, N. (2011): "Enforced Disappearances in Cyprus: Problems and Prospects of the Case Law of the European Court of Human Rights", en: European Human Rights Law Review, (Vol. 2), pp. 190-199.

Kress, Claus. (2010): "On the Outer Limits of Crimes against Humanity: The Concept of Organization within the Policy Requirement: Some Reflections on the March 2010 ICC Kenya Decision", Leiden Journal of International Law, (Vol. 23, Issue 4), pp. 855-873.

Linghammar, Philipp (2009): "A study of the international legal instruments addressing enforced disappearance", en: Lunds Universitet-Human Rights Studies. Disponible en: http://lup.lub.lu.se/luur/download?func=downloa $d$ File\&recordOId=1316380\&fileOId=1316381 [Visitado el 22.11.2017].

López Díaz, Claudia (2009): "Colombia", en: Ambos, Kai y Correa, Juliana (coordinadores), Desapariciones forzadas de personas. Análisis comparado e internacional (Bogotá, Temis), pp. 77-103.

MalarINO, Ezequiel (2003): “La policía en los Estados de Derecho Latinoamericanos: un resumen comparativo", en: Ambos, Kai, Gómez-Colomer, Juan-Luis y Vogler, Richard (editores), La policía en los estados de Derecho latinoamericanos. Un proyecto internacional de investigación (Bogotá-Medellín, Instituto Max Planck para el Derecho Penal Extranjero e InternacionalEdiciones Jurídicas Gustavo Ibáñez), pp. 577-627.

Manero Salvador, Ana (2012): "Colombia y la responsabilidad internacional por desapariciones forzadas", en: Anuario Español de Derecho Internacional ( No 28), pp. 106-141.

Mañalich, Juan Pablo (2004): "El secuestro como delito permanente frente al D.L. de amnistía", Revista de Estudios de la Justicia (№ 5), pp. 11-33.

Matus, Jean Pierre (2006): "Informe pericial ante Corte Interamericana de Derechos Humanos, sobre aplicación jurisprudencial de Decreto Ley № 2.191 de amnistía, de fecha 19 de abril de 1978", Ius et Praxis, (Vol. 12, No 1), pp. 275-296. Disponible en <https://scielo.conicyt.cl/scielo. 
php? script=sci_arttext\&pid=S0718-00122006000100012>. [Visitado el 24.08.2018].

Matus Acuña, Jean Pierre; Ramírez Guzmán, María Cecilia (2017): Manual de Derecho penal chileno. Parte especial. (Valencia: Tirant lo Blanch).

McCrorr, Susan (2007): "The International Convention for the Protection of all Persons from Enforced Disappearance", en: Human Rights Law Review (Vol. 7, No 3), pp. 545-566.

MeINI, Iván (2009): "Perú", en: Ambos, Kai y Correa, Juliana (coordinadores), Desapariciones forzadas de personas. Análisis comparado e internacional (Bogotá, Temis), pp. 106-131.

Melzer, Nils (2016): International Humanitarian Law. A Comprehensive Introduction, (Geneva, ICRC).

Modolell GonzÁlez, Juan Luis (2009): “La desaparición forzada de personas en el sistema interamericano de derechos humanos", en: Ambos, Kai y Correa, Juliana (coordinadores), Desapariciones forzada de personas. Análisis comparado e internacional (Bogotá, Temis), pp. 180-193.

Modolell González, Juan Luis (2010): “El crimen de desaparición forzada de personas según la jurisprudencia de la Corte Interamericana de Derechos Humanos", en: Ambos, Kai; Malarino, Ezequiel, y Elsner, Gisela (editores), Sistema Interamericano de Protección de los Derechos Humanos y Derecho Penal Internacional (Montevideo, Konrad-Adenauer-Stiftung), pp. 193-209.

Müller, Jörg Paul y Cottier, Thomas (1992): "Acquiescence", en: Bernhardt, Rudolf (director), Encyclopedia of Public International Law (AmsterdamLondon-New York-Tokyo, North-Holland), t. I, pp. 14-16.

NowAK, Manfred y McArthur, Elizabeth (2008): The United Nation Convention Against Torture. A Commentary (Oxford, Oxford University Press).

Otт, Lisa (2011): Enforced Disappearances in International Law (CambridgeAntwerp-Portland, Intersentia).

Parayre, Sonia (1999): "La desaparición forzada de personas como violación continuada de los derechos humanos y su incidencia en la determinación de la competencia ratione temporis de la Corte Interamericana de los derechos humanos", en: Revista del Instituto Interamericano de Derechos Humanos, (Vol. 29), pp. 25-67.

Pérez Solla, María Fernanda (2006): Enforced Disappearances in International Human Rights (Jefferson, McFarland \& Company).

Rodley, Nigel y Pollard, Matt (2009): The Treatment of Prisoners under International Law, $3^{\mathrm{a}}$ ed. (Oxford, Oxford University Press). 
Rodríguez-Pinzón, Diego y MARTin, Claudia (2006): The Prohibition of Torture and III-Treatment in the Inter-American Human Rights System. A Handbook for Victims and their Advocates (Ginebra, World Organization against Torture).

RonZITTI, Natalino (1965): "La cattura di un individuo all'estero: in margine al caso Argoud", en: Rivista di diritto internazionale (Vol. XLVIII, № 1), pp. 64-79.

Rousseau, Charles (1930): "L'aménagement de compétences en Droit international", en: Revue Générale de Droit International Public (Vol. XXXVII), pp. 420-460.

SADAT, Leila Nadya (2002): The International Criminal Court and the Transformation of International Law: Justice for the New Millennium (Ardsley, Transnational Publishers).

SADAT, Leila Nadya (2013): "Crimes Against Humanity in the Modern Age", en : The American Journal of International Law (Vol. 107, № 2), pp. 334-377.

Salmon, Jean (2010): "Duration of the Breach", en: Crawford, James et al. (editores), The Law of International Responsibility (Oxford: Oxford University Press), pp. 383-396.

Scovazzı, Tullio y Citronı, Gabriella (2007): The Struggle against Enforced Disappearance and the 2007 United Nation Convention (Leiden-Boston, Martinus Nijhoff).

Sferrazza Taibı, Pietro (2018): “La desaparición forzada como hecho ilícito permanente en la jurisprudencia de la Corte Interamericana de Derechos Humanos", en: Revista de Derecho (Valdivia), (Vol. 31, № 1), pp. 185-207.

StahN, Carsten (2014): "Justice Delivered or Justice Denied? The Legacy of the Katanga Judgment", en: Journal of International Criminal Justice (Vol. 12), pp. 809-834.

Stevens, Philip (2010): "The International Convention on the Protection of All Persons from Enforced Disappearances-A Welcoming Response to a Worldwide Phenomenon with Limited Relief", en: Tydskrif vir hedendaagse Romeins-Hollandse Reg./ Journal of Contemporary Roman-Dutch Law (Vol. 73, No 3), pp. 368-383.

Vermeulen, Marthe Lot (2011): "The Duty to Take Preventive operational Measures. An Adequate Legal Tool to Hold States Responsible in Enforced Disappearance Cases?", en: Buyse, Antoine, Margins of Conflict. The ECHR and Transitions to and from Armed Conflict (Cambridge-Antwerp-Portland, Intersentia), pp. 153-174. 
Vermeulen, Marthe Lot (2012): Enforced Disappearance. Determining State Responsibility under the International Convention for the Protection of All Persons from Enforced Disappearance (Cambridge-Antwerp-Portland, Intersentia).

ViBHUTE, Khushal (2008): "The 2007 International Convention against Enforced Disappearance: Some Reflections", en: Mizan Law Review (Vol. 2, № 2), pp. 287-310.

VILLÁN DURÁn, Carlos (1985): "La Convención contra la Tortura y su contribución a la definición del derecho a la integridad física y moral en el Derecho internacional", en: Revista Española de Derecho Internacional (Vol. 37, $\left.N^{\circ} 2\right)$, pp. 377-402.

VRANCKX, An (2007): "A Long Road towards Universal Protection against Enforced Disappearance", en: International Peace Information Service. Disponible en: https://biblio.ugent.be/publication/371025 [Visitado el 22.11.2017].

Werle, Gerhard (2011): Tratado de Derecho Penal Internacional, $2^{\mathrm{a}}$ ed. (traducc. Claudia Cárdenas Aravena et al., Valencia, Tirant lo Blanch).

Werle, Gerhard y Burghardt, Boris (2012): "Do Crimes Against Humanity Require the Participation of a State or a 'State-like' Organization?", en: Journal of International Criminal Justice (Vol. 10), pp. 1151-1170.

WitsChel, Georg y RüCKeRT, Wiebke (1999): "Article 7(1)(i)-Crime Against Humanity of Enforced Disappearance of Persons", en: Lee, Roy S. (editor), The International Criminal Court: The Making of the Rome Statute (La HayaLondres-Boston, Kluwer Law International-Martinus Nijhoff Publishers), pp. 98-103.

\section{JURISPRUDENCIA CONSULTADA}

Comité contra las Desapariciones Forzadas. Estela Deolinda Yrusta y Alejandra del Valle Yrusta, CED/C/10/D/1/2013, 12 de abril de 2016.

Comité de Derechos Humanos. A v. Australia, comunicación № 560/1993, 3 de abril 1997.

Comité de Derechos Humanos. Spakmo (initially represented by Mr. Gustav Hogtun) v. Norway, comunicación Nº 631/1995, 11 de noviembre de 1999.

Comité de Derechos Humanos. Van Alphen v. The Netherlands, comunicación No 305/1988, 23 de julio de 1990.

Comité de Derechos Humanos. Yasoda Sharma v. Nepal, comunicación No 1469/2006, 28 de octubre de 2008. 
Comité de Derechos Humanos. Zohra Madoui v. Algeria, comunicación No 1495/2006, 28 de octubre de 2008.

Comité Europeo para la Prevención de la Tortura y de las Penas o Tratos Inhumanos o Degradantes (2000). Report to the Spanish Government on the visit to Spain carried out by the European Committee for the Prevention of Torture and Inhuman or Degrading Treatment or Punishment (CPT) from 22 November to 4 December 1998, CPT/Inf. (2000) 5, 13 de abril de 2000.

Comité Europeo para la Prevención de la Tortura y de las Penas o Tratos Inhumanos o Degradantes (2003). Report to the Spanish Government on the visit to Spain carried out by the European Committee for the Prevention of Torture and Inhuman or Degrading Treatment or Punishment (CPT) from 22 to 26 July 2001, CPT/Inf. (2003) 30, 13 de marzo de 2003.

Corte Interamericana de Derechos Humanos. Blanco Romero y otros vs. Venezuela. Fondo, Reparaciones y Costas. Sentencia de 28 de noviembre de 2005. Serie $C \mathrm{~N}^{\circ} 138$.

Corte Interamericana de Derechos Humanos. Blake v. Guatemala. Fondo. Sentencia de 24 de enero de 1998. Serie C No 36.

Corte Interamericana de Derechos Humanos. Castillo Petruzzi y otros v. Perú. Fondo, Reparaciones y Costas. Sentencia de 30 de mayo de 1999. Serie C No 52 .

Corte Interamericana de Derechos Humanos. Chaparro Álvarez y Lapo Íñiguez v. Ecuador. Excepciones Preliminares, Fondo, Reparaciones y Costas. Sentencia de 21 de noviembre de 2007. Serie C N 170.

Corte Interamericana de Derechos Humanos. Chitay Nech y otros v. Guatemala. Excepciones Preliminares, Fondo, Reparaciones y Costas. Sentencia de 25 de mayo de 2010. Serie C No 212.

Corte Interamericana de Derechos Humanos. Gangaram Panday v. Surinam. Fondo, Reparaciones y Costas. Sentencia de 21 de enero de 1994. Serie C No 16. Corte Interamericana de Derechos Humanos. Gómez Palomino v. Perú. Fondo, Reparaciones y Costas. Sentencia de 22 de noviembre de 2005. Serie C $\mathrm{N}^{\circ} 136$.

Corte Interamericana de Derechos Humanos. Gomes Lund y otros ("Guerrilha do Araguaia") v. Brasil. Excepciones Preliminares, Fondo, Reparaciones y Costas. Sentencia de 24 de noviembre de 2010. Serie C No 219.

Corte Interamericana de Derechos Humanos. Heliodoro Portugal v. Panamá. Excepciones Preliminares, Fondo, Reparaciones y Costas. Sentencia de 12 de agosto de 2008. Serie C No 186. 
Corte Interamericana de Derechos Humanos. Ibsen Cárdenas e Ibsen Peña v. Bolivia. Fondo, Reparaciones y Costas. Sentencia de 1 de septiembre de 2010. Serie C No 217.

Corte Interamericana de Derechos Humanos. Masacre de Mapiripán v. Colombia. Sentencia de 15 de septiembre de 2005. Serie C № 134.

Corte Interamericana de Derechos Humanos. Masacre de Pueblo Bello v. Colombia. Sentencia de 31 de enero de 2006. Serie C No 140.

Corte Interamericana de Derechos Humanos. Masacres de Río Negro v. Guatemala. Excepción Preliminar, Fondo, Reparaciones y Costas. Sentencia de 4 de septiembre de 2012 Serie C No 250.

Corte Interamericana de Derechos Humanos. Masacre Plan de Sánchez v. Guatemala. Fondo. Sentencia de 29 de abril de 2004. Serie C № 105.

Corte Interamericana de Derechos Humanos. Osorio Rivera y familiares v. Perú. Excepciones Preliminares, Fondo, Reparaciones y Costas. Sentencia de 26 de noviembre de 2013. Serie C N 274.

Corte Interamericana de Derechos Humanos. Radilla Pacheco v. México. Excepciones Preliminares, Fondo, Reparaciones y Costas. Sentencia de 23 de noviembre de 2009. Serie C No 209.

Corte Interamericana de Derechos Humanos. Suárez Rosero v. Ecuador. Fondo. Sentencia de 12 de noviembre de 1997. Serie C No 35.

Corte Interamericana de Derechos Humanos. Torres Millacura y otros v. Argentina. Fondo, Reparaciones y Costas. Sentencia de 26 de agosto de 2011. Serie C $N^{\circ} 229$.

Corte Penal Internacional. SCP II. Jean-Pierre Bemba Gombo. Decision Pursuant to Article 61(7)(a) and (b) of the Rome Statute on the Charges of the Prosecutor Against Jean-Pierre Bemba Gombo, ICC-01/05-01/08-424, 15 de junio de 2009.

Corte Penal Internacional. SCP I. Katanga and Ngudjolo. Decision on the confirmation of charges. ICC-01/04-01/07-717, 30 de septiembre de 2008.

Corte Penal Internacional. SCP II. Decision Pursuant to Article 15 of the Rome Statute on the Authorization of an Investigation into the Situation in the Republic of Kenya. ICC-01/09-19, 31 de marzo de 2010.

Corte Penal Internacional. SCP II. Muthaura et al. Decision on the Confirmation of Charges. ICC-01/09-02/11-382-Red, 23 de enero de 2012.

Corte Penal Internacional. SCP II. Ruto et al. Decision on the Confirmation of Charges. ICC-01/09-01/11-373, 23 de enero de 2012. 
Corte Penal Internacional. SCP III. Corrigendum to "Decision Pursuant to Article 15 of the Rome Statute on the Authorisation of an Investigation into the Situation in the Republic of Côte d'Ivoire", ICC-02/11-14-Corr, 15 de noviembre de 2011.

CORTE SuPREMA, rol No 517-2004, 17 de noviembre de 2004.

Corte Suprema, rol No 559-2004, 13 de diciembre de 2006.

Corte Suprema, rol No 3452-2006, 10 de mayo de 2007.

Tribunal Europeo de Derechos Humanos. Grand Chamber. A. and others v. The United Kingdom, application No 3455/05, 19 de febrero de 2009.

Tribunal Europeo de Derechos Humanos. Brannigan and McBride v. The United Kingdom, judgment, application $\mathrm{N}^{\circ}$ 14553/89; 14554/89, 25 de mayo de 1993.

Tribunal Europeo de Derechos Humanos. Brogan and others v. The United Kingdom, judgment, application $\mathrm{N}^{\circ}$ s. 11209/84; 11234/84; 11266/84; 11386/85, 29 de noviembre de 1988.

Tribunal Europeo de Derechos Humanos. Ipek and Others v. Turkey, applications

$\mathrm{N}^{\circ}$ s. 17019/02 and 30070/02, judgment, 3 de febrero de 2009.

Tribunal Europeo de Derechos Humanos. Kandzhov v. Bulgaria, application $N^{\circ}$ 68294/01, judgment, 6 de noviembre de 2008.

Tribunal Europeo de Derechos Humanos. Kaya v. Turkey, application № 22535/93, judgment, 28 de marzo de 2000.

Tribunal Europeo de Derechos Humanos. Koku v. Turkey, application № 27305/95, judgment, 31 de mayo de 2005.

Tribunal Europeo de Derechos Humanos. Kukayev v. Russia, application No 29361/02, judgment, 15 de noviembre de 2007.

Tribunal Europeo de Derechos Humanos. Kurt v. Turkey, (15/1997/799/1002), judgment, 25 de mayo de 1998.

Tribunal Europeo de Derechos Humanos. Grand Chamber. McKay v. The United Kingdom, application № 543/03, judgment, 3 de octubre de 2006.

Tribunal Europeo de Derechos Humanos. Grand Chamber. Öcalan v. Turkey, judgment, application No 46221/99, judgment, 12 de mayo de 2005.

Tribunal Europeo de Derechos Humanos. Osmanoğlu v. Turkey, application No 48804/99, judgment, 24 de enero de 2008.

Tribunal Europeo de Derechos Humanos. Pantea v. Romania, judgment, application No 33343/96, judgment, 3 de junio de 2003. 
Tribunal Europeo de Derechos Humanos. Süleyman Yildirim v. Turkey, application No 40518/98, judgment, 29 de julio de 2004.

Tribunal Europeo de Derechos Humanos. Van der Leer V. The Netherlands, application $N^{\circ}$ 11509/85, judgment, 21 de febrero de 1990.

\section{DOCUMENTOS CONSULTADOS}

Amnistía Internacional (1998): Juicios Justos, Londres, Amnesty International Publications.

Asamblea General (2006): Department of Public Information. Third Committee Approves Draft Resolution concerning Convention on Enforced Disappearances. GA/SHC/3872, 13 de noviembre de 2006.

Asamblea General (2006b): 82a sesión plenaria. A/61/PV.82, 20 de diciembre de 2006.

Asamblea General (2007): Acta resumida de la $45^{a}$ sesión. Sexagésimo primer período de sesiones. A/C.3/61/SR.45, 5 de enero de 2007.

Asamblea General (1990): Informe del Comité de derechos Humanos. Vol. I. A/45/40, 4 de octubre de 1990.

Asamblea Parlamentaria del Consejo de Europa (2005): Enforced Disappearances. Report Committee on Legal Affairs and Human Rights. Rapporteur: Mr. Christos Pourgourides. Doc. 10679, 19 de septiembre 2005.

Asamblea Parlamentaria del Consejo de Europa (2005b): Enforced disappearances. Report Committee on Legal Affairs and Human Rights. Rapporteur: Mr. Christos Pourgourides. Doc. 10679, 19 de septiembre 2005.

Asamblea Parlamentaria del Consejo de Europa (2005c): Res. № 1.463 (2005), Enforced disappearances, 3 de octubre de 2005.

Asamblea Parlamentaria del Consejo de Europa (2012): Res. № 1.868 (2012), The International Convention for the Protection of all Persons from Enforced Disappearance, 9 de marzo de 2012.

Association for the Prevention of Torture (2006): Incommunicado, Unacknowledged and Secret Detention under International Law. Disponible en: https://www.apt.ch/content/files_res/secret_detention_apt1-1.pdf [Visitado el 23.11.2017].

Comisión Africana de Derechos Humanos y de los Pueblos (2002): Resolution on Guidelines and Measures for the Prohibition and Prevention of Torture, Cruel, Inhuman or Degrading Treatment or Punishment in Africa, Res. № 61 (XXXII) 02 de la ACHPR, Banjul, Gambia, 17 al 23 de octubre de 2002. 
Comisión Africana de Derechos Humanos y de los Pueblos (1992): Resolution on the Right to Recourse and FaIR Trial, Res. № 4(XI)92, Túnez, Republica Tunecina, 2 al 9 de marzo de 1992.

Comisión Africana de Derechos Humanos y de los Pueblos (2011): Principles and Guidelines on the Right to a Fair Trial and Legal Assistance in Africa, Túnez, República Tunecina, 24 de octubre de 2011.

Comisión de Derecho Internacional (2001). Proyecto de artículos sobre responsabilidad internacional del Estado. En: Comisión de DereCho INTERnaCional. Informe de la Comisión de Derecho Internacional, $53^{\circ}$ período de sesiones (23 de abril a 1 de junio y 2 de julio a 10 de agosto de 2001), A/56/10, pp. 21-405.

Comisión de Derechos Humanos (2002): Los derechos civiles y políticos, en particular las cuestiones relacionadas con las desapariciones y las ejecuciones sumarias. Informe presentado por el Sr. Manfred Nowak, experto independiente encargado de examinar el marco internacional existente en materia penal y de derechos humanos para la protección de las personas contra las desapariciones forzadas o involuntarias, de conformidad con el párrafo 11 de la Resolución № 2.001/46 de la Comisión en $58^{\circ}$ período de sesiones. E/CN.4/2002/71, 8 de enero de 2002.

Comisión de Derechos Humanos (2003): Los derechos civiles y políticos, en particular la cuestión relacionada con las desapariciones forzadas o involuntarias. Informe del Grupo de Trabajo entre períodos de sesiones, de composición abierta, encargado de elaborar un proyecto de instrumento normativo jurídicamente vinculante para la protección de todas las personas contra las desapariciones forzadas. E/CN.4/2003/71, 12 de febrero de 2003.

Comisión de Derechos Humanos (2004): Los derechos civiles y políticos, en particular la cuestión relacionada con las desapariciones forzadas o involuntarias. Informe del Grupo de Trabajo entre períodos de sesiones, de composición abierta, encargado de elaborar un proyecto de instrumento normativo jurídicamente vinculante para la protección de todas las personas contra las desapariciones forzadas. E/CN.4/2004/59, 23 de febrero de 2004.

Comisión de Derechos Humanos (2004b): Los derechos civiles y políticos, en particular las cuestiones relacionadas con las desapariciones y las ejecuciones sumarias. Las ejecuciones extrajudiciales, sumarias o arbitrarias. Informe del Relator Especial, Philip Alston. E/CN.4/2005/7, 22 de diciembre de 2004. 
Comisión de Derechos Humanos (2005): Los derechos civiles y políticos, en particular la cuestión relacionada con las desapariciones forzadas o involuntarias. Informe del Grupo de Trabajo entre períodos de sesiones, de composición abierta, encargado de elaborar un proyecto de instrumento normativo jurídicamente vinculante para la protección de todas las personas contra las desapariciones forzadas. E/CN.4/2005/66, 10 de marzo de 2005.

Comisión de Derechos Humanos (2006): Los derechos civiles y políticos, en particular la cuestión relacionada con las desapariciones forzadas o involuntarias. Informe del Grupo de Trabajo entre períodos de sesiones, de composición abierta, encargado de elaborar un proyecto de instrumento normativo jurídicamente vinculante para la protección de todas las personas contra las desapariciones forzadas. E/CN.4/2006/57, 2 de febrero de 2006.

Comisión de Derechos Humanos (2007): Aplicación de la resolución 60/251 de la Asamblea General, de 15 de marzo de 2006, titulada "Consejo de Derechos Humanos". Informe del Grupo de Trabajo sobre Desapariciones Forzadas o Involuntarias. Adición. Misión a Guatemala. A/HRC/4/41/Add.1, 20 de febrero de 2007.

Comisión Nacional de Verdad y ReCOnCILIACión (1996): Informe de la Comisión Nacional de Verdad y Reconciliación, reedición, 2 vols., Santiago de Chile.

Comité contra las Desapariciones Forzadas (2013): Observaciones finales sobre el informe presentado por Francia en aplicación del artículo 29, párrafo 1, de la Convención, aprobadas por el Comité en su cuarto período de sesiones (8 a 19 de abril de 2013). CED/C/FRA/CO/1, 8 de mayo de 2013.

Comité Contra las Desapariciones Forzadas (2014): Observaciones finales sobre el informe presentado por el Paraguay en virtud del artículo 29, párrafo 1, de la Convención. CED/C/PRY/CO/1, 20 de octubre de 2014.

Comité COntra las Desapariciones Forzadas (2015): Observaciones finales sobre el informe presentado por el Iraq en virtud del artículo 29, párrafo 1, de la Convención, CED/C/IRQ/CO/1, 13 de octubre de 2015.

Comité contra las Desapariciones Forzadas (2016): Observaciones finales sobre el informe presentado por Colombia en virtud del artículo 29, párrafo 1, de la Convención. CED/C/COL/CO/1, 27 de octubre de 2016.

Comité Contra las Desapariciones Forzadas (2017): Observaciones finales sobre el informe presentado por el Senegal en virtud del artículo 29, párrafo 1, de la Convención. CED/C/SEN/CO/1, 18 de abril de 2017. 
Comité de Derechos Humanos (2008). Observación General Nº 8. Derecho a la libertad y a la seguridad personales (artículo 9). En: ONU. Instrumentos internacionales de derechos humanos. 2 Vols. Volumen I. Recopilación de las observaciones generales y recomendaciones generales adoptadas por órganos creados en virtud de tratados de derechos humanos. HRI/GEN/1/ Rev.9 (Vol. I), 27 de mayo de 2008.

COMISIÓN INTERNACIONAL DE JURISTAS (2015): Desaparición forzada y ejecución extrajudicial: investigación y sanción Guía para profesionales No 9 (Ginebra, Comisión Internacional de Juristas).

Consejo de Derechos Humanos (2010): Informe del Grupo de Trabajo sobre las Desapariciones Forzadas o Involuntarias. Adición. Mejores prácticas de la legislación penal nacional en materia de desapariciones forzadas. A/HRC/16/48/Add.3, 28 de diciembre de 2010.

Consejo Económico y Social (2002): Res. № 2.002/16, Cooperación internacional en prevenir combatir y eliminar el secuestro y en prestar asistencia a las víctimas, 24 de julio de 2002.

Consejo Económico y Social (2003): Comisión de Prevención del Delito y Justicia Penal. Cooperación internacional en prevenir, combatir y eliminar el secuestro y en prestar asistencia a las víctimas. Informe del Secretario General. E/CN.15/2003/7, 5 de marzo de 2003.

Corporación Nacional de Reparación y Reconciliación (1996). Informe sobre calificación de víctimas de violaciones de derechos humanos y de la violencia política, Santiago de Chile.

Grupo de Trabajo sobre Desapariciones Forzadas e Involuntarias (1996): Observaciones generales sobre el artículo 10 de la Declaración, en: Consejo Económico y Social. Comisión de Derechos Humanos. Cuestión de los derechos humanos de todas las personas sometidas a cualquier forma de detención o prisión. Cuestión de las desapariciones forzadas o involuntarias. Informe del Grupo de Trabajo sobre Desapariciones Forzadas e Involuntarias. E/CN.4/1997/34, 13 de diciembre de 1996, párrs. 22-30.

Grupo de Trabajo sobre Desapariciones Forzadas e Involuntarias (2008): Comentario general sobre la definición de desaparición forzada, en: Consejo de Derechos Humanos. Promoción y protección de todos los derechos humanos, civiles, políticos, económicos, sociales y culturales, incluido el derecho al desarrollo. Informe del Grupo de Trabajo sobre las Desapariciones Forzadas o Involuntarias. A/HRC/7/2, 10 de enero de 2008.

Real Academia Española (2018): "Diccionario de la lengua española". Disponible en: http://dle.rae.es/?w=diccionario [Visitado el 7.11.2017]. 
Subcomisión de Prevención de Discriminaciones y Protección a las Minorías (1996): La administración de justicia y los derechos humanos de los detenidos. Informe del Grupo de Trabajo del período de sesiones sobre la administración de justicia y la cuestión de la indemnización. E/CN.4/Sub.2/1996/16, 13 de agosto de 1996.

Subcomisión de Prevención de Discriminaciones y Protección a las Minorías (1998):

La administración de justicia y los derechos humanos. Informe del Grupo de Trabajo del período de sesiones sobre la administración de la justicia. E/CN.4/Sub.2/1998/19, 19 de agosto de 1998. 
